\title{
Movimentos sociais e partidos políticos: as relações entre o movimento feminista e o sistema de partidos na Nicarágua (1974-2012)*
}

Humberto Meza

Luciana Tatagiba

\section{Introdução}

Os partidos são jogadores importantes na política contenciosa, na medida em que moldam, pelo menos em parte, as oportunidades e os resultados dos movimentos sociais (McAdam, Tarrow e Tilly, 2001). Da mesma forma, os movimentos contribuem para a modelagem das disputas eleitorais, podendo até mesmo dar surgimento a novos partidos, como o Partido dos Trabalhadores no Brasil, a FSLN na Nicarágua, o Tea Party nos Estados Unidos ou o Podemos na Espanha. Ou seja, partido e movimentos são mutuamente constitutivos e a natureza de suas relações importa para a democracia e para os processos de mudança social (Goldstone, 2003; Tilly, 2008; McAdam e Tarrow, 2011.

Contudo, ambos ainda costumam ser tratados como mundos à parte e, de modo geral, os pesquisadores dos dois campos tendem a nutrir uma "indiferença recíproca" (McAdam e Tarrow, 2011). Na América Latina, há até bem pouco tempo, o que predominava nas ciências sociais era uma visão purista segundo a qual a aproximação com a política institucional iria macular os movimentos, visão traduzida por Hellman como o "fetichismo da autonomia" (Hellman, 1992).

Hoje em dia, abordagens mais relacionais e históricas têm permitido superar dicotomias e essencialismos e investigar empiricamente as relações entre política contestatória e política institucional e os seus resultados.

\footnotetext{
* A produção deste artigo, em suas várias versões, se beneficiou de um generoso diálogo com vários pesquisadores e ativistas. Uma primeira versão deste texto foi apresentada por Humberto Meza no $38^{\circ}$ Encontro da Anpocs de 2014, no GT "Entre as ruas e os gabinetes: institucionalização e contestação nos movimentos sociais". Os autores agradecem aos debatedores e aos presentes as sugestões recebidas, especialmente a José Leon Szwako. Agradecemos também aos integrantes do Núcleo de Pesquisa em Participação, Movimentos Sociais e Ação Coletiva (Nepac-Unicamp) pela discussão coletiva da segunda versão do texto, e a Evelina Dagnino e Milly Thayer pela leitura atenta e as pertinentes sugestões. A Sônia Alvarez, Hilary Wainwright e Valeriano Mendes Ferreira Costa agradecemos as contribuições feitas ainda na fase de elaboração da tese que ofereceu subsídios a este artigo (Meza, 2015). Também agradecemos aos entrevistados e informantes na Nicarágua o tempo que nos foi concedido e o entusiasmo com que receberam esse projeto, em especial às ativistas do MAM, à pesquisadora feminista Ana Criquillon e às dirigentes da Red de Mujeres Contra la Violencia. Aos pareceristas anônimos da revista Opinião Pública agradecemos os comentários decisivos para o fechamento do nosso argumento. Somos realmente gratos a todos pela partilha.
} 
O left turn em vários países da região que ampliaram a inserção institucional dos movimentos nos partidos de esquerda e no Estado contribuiu para esses deslocamentos analíticos. Contudo, apesar dos avanços, o tema da relação entre movimentos sociais e partidos não tem sido tratado de forma sistemática e segue, no geral, subteorizado. Este artigo tem como objetivo contribuir para preencher essa lacuna.

Nossa discussão está baseada em uma pesquisa acerca das relações entre os partidos e o movimento feminista na Nicarágua. A escolha por esse estudo de caso foi motivada por um fato singular: em 2006, uma das mais importantes organizações do movimento feminista na Nicarágua, o Movimiento Autónomo de Mujeres (MAM), subscreveu uma aliança formal em cartório com um partido político, o Movimiento de Renovación Sandinista (MRS). A aliança significava para ambos a chance de atuar na política em um contexto adverso, caracterizado pelo retorno ao poder de Daniel Ortega, da Frente Sandinista de Liberación Nacional (FSLN). A estratégia era influenciar as eleições com o lançamento de candidaturas próprias costuradas no âmbito da aliança. Esse foi o nosso ponto de entrada no campo. Mas no processo da pesquisa identificamos que a aliança era um retrato de um momento dessa relação entre o movimento feminista e o sistema de partidos, e que, para compreendê-la, era preciso recuperar o processo que foi se configurando ao longo das últimas décadas no lastro da construção democrática nesse país centro-americano. Nesse sentido é que delimitamos nosso marco temporal iniciando em 1974, ano que marca a atuação mais incisiva das mulheres no movimento guerrilheiro contra a ditadura de Somoza, até 2012, quando, buscando enfrentar nova vitória de Ortega nas eleições presidenciais, MAM e MRS lideram uma frente de mobilização nacional contra o governo.

O movimento feminista na Nicarágua é complexo e heterogêneo e encontra na defesa da autonomia em relação às instituições políticas um ponto importante de convergência entre as organizações que o constitui. Ou seja, a autonomia é um valor que baliza diferentes estratégias de interação com os partidos a depender do grupo que a professa e das oportunidades e ameaças que esse grupo identifica no seu contexto de atuação. O grupo de feministas que estudamos, que criou o Movimiento Autónomo de Mujeres (MAM), tem como característica distintiva a estratégia de influenciar o sistema político. Sua agenda tem como objetivo central a democratização do Estado e do sistema de partidos a partir de uma orientação de gênero. Por isso, sempre que precisarmos diferenciá-las da rede ampla do feminismo na Nicarágua nos referiremos a elas como "feministas políticas", embora tenhamos plena consciência de que todo feminismo é político (Miguel e Biroli, 2014).

O Movimiento Autónomo de Mujeres (doravante MAM) foi criado oficialmente em 2006, mas suas origens datam da metade dos anos de 1970, quando parte de suas lideranças se engajou na luta armada contra a ditadura de Somoza. Embora o confronto guerrilheiro fosse o repertório privilegiado naquela época, nem todas assumiram a luta armada. Algumas se vincularam às pastorais universitárias e aos diversos Comitês 
Eclesiais de Base (Cebs), desde onde adotaram diversas estratégias de luta contra a repressão. Já depois do triunfo revolucionário de 1979, todas assumiram funções dentro do Estado revolucionário e também nos sindicatos. O MAM surge assim no interior de um grande campo de esquerda unido pela defesa do sandinismo como projeto político de nação.

Com o fim da revolução e uma consciência feminista em formação, as feministas buscam conquistar autonomia organizacional e estratégica, gerando inúmeros conflitos e a ruptura definitiva com a esquerda partidária, a Frente Sandinista de Liberación Nacional (FSLN), que atuava como um partido de vanguarda. Para continuar atuando na política, as feministas políticas buscam um novo parceiro partidário e o encontram no Movimiento de Renovación Sandinista (MRS). Assim como o MAM, a história do MRS está associada à luta revolucionária contra a ditadura, e seu surgimento, em 1995, está ligado aos conflitos com Daniel Ortega, o principal líder da FSLN, em torno da identidade sandinista. Como foi relatado por uma das entrevistadas para esta pesquisa, diante do fechamento dos canais de acesso ao Estado, o MAM "montava no cavalo do MRS" para conseguir provocar mudanças no Congresso e no sistema de partidos a favor de uma agenda de gênero, consubstanciada nos temas do aborto, da violência contra as mulheres e das cotas na política.

O saldo dessa aposta foi ambíguo. Ortega segue dominando o quadro eleitoral, mas MAM e MRS não só mantiveram a parceria, lançando candidatos novamente em 2016, como lideraram a principal estrutura de mobilização contra o governo de Ortega entre 2010 e 2012. Em termos das políticas públicas, o governo combinou a criminalização do movimento feminista, principalmente o MAM, com a incorporação de algumas de suas pautas, dentre as quais a lei que assegura $50 \%$ de mulheres nas indicações partidárias. Por outro lado, é um país que criminaliza todas as formas de aborto e que tem assistido a um aumento significativo dos indicadores de violência de gênero. Para as feministas políticas, a parceria com o MRS significou a oportunidade para acessar o sistema político, mas com um alto custo no que se refere à identidade e à coesão interna do movimento, principalmente pelo mimetismo organizacional do MAM com a forma partidária.

Para contar essa história e analisar seus resultados, o artigo se baseia em uma pesquisa de campo realizada entre 2011 e 2014 em quatro cidades da Nicarágua, como parte do processo de realização da tese de doutorado de Humberto Meza ${ }^{1}$. Foram realizadas 23 entrevistas com lideranças feministas do MAM, da Red de Mujeres Contra la Violencia, do Movimiento Feminista e da Coordinadora de Mujeres Rurales, assim como entrevistas semiestruturadas com deputados do MRS e membros do diretório do MRS e do Partido Liberal Independiente (PLI). A pesquisa consistiu ainda em observação

\footnotetext{
${ }^{1}$ A tese intitulada "Autonomia em movimento. Análise da trajetória de relações do movimento de mulheres com os partidos políticos na Nicarágua pós-revolucionária" foi defendida em outubro de 2015, no Programa de Pós-Graduação em Ciência Política da Unicamp, sob a orientação de Luciana Tatagiba.
} 
participante nas assembleias deliberativas do MAM (exceto o Congresso Nacional do movimento, em que foi negada a participação do pesquisador por ser homem), debate com pesquisadoras do feminismo nicaraguense, especialmente com Ana Criquillon, e análise dos documentos produzidos pelo MAM e MRS, no âmbito da aliança.

$\mathrm{E}$ o que esse caso nos permite concluir acerca das relações entre o movimento feminista e os partidos? Em primeiro lugar, nos permitiu reconhecer a natureza modular da autonomia. Ao adotar um marco temporal relativamente amplo, de 1974 a 2016, nossa pesquisa nos possibilitou apreender as variações nas relações entre o movimento feminista e os partidos ao longo do tempo. Vimos que em vez da dicotomia autonomia $x$ cooptação, forma como a relação entre os atores fora apreendida no passado, há uma gama mais rica e complexa de interações, identificadas no nosso caso em torno de três fases: incorporação, ruptura e aliança, essa última dividida em aliança instrumental e aliança por projeto. Autonomia não significou ausência de relação, mas, pelo contrário, era uma reivindicação discursiva e uma estratégia de interação cujo conteúdo variava em função do contexto político da interação. Os conteúdos da autonomia são expressão de processos relacionais. É nesse sentido que nos referimos à modularidade da autonomia.

Em segundo lugar, nossa pesquisa também nos permitiu refletir sobre como a relação movimento-partido se vincula ao tema da mudança social. A aliança entre MAM e MRS gerou um terceiro espaço, um espaço intermédio, que aqui chamamos de zona de interseção. Nesse espaço, movimento e partido transacionam, estabelecem negociações, geram novas estruturas, incluem novos parceiros. A zona de interseção é acionada quando, para responder às ameaças e oportunidades do contexto, partido e movimento se aliam e, sob a reivindicação da autonomia recíproca, coordenam suas ações provocando mudanças no contexto político, as quais, por sua vez, alteram os cenários das lutas futuras.

Este artigo está divido em três seções. Na primeira, "A relação entre movimentos sociais e partidos políticos", estabelecemos um diálogo com a literatura que trata da relação entre esses movimentos e as instituições políticas, buscando localizar suas lacunas e apontar nossas possíveis contribuições ao avanço desse debate. Na sequência, em "A relação entre o movimento feminista e o sistema de partidos na Nicarágua (19742012)", apresentamos nosso estudo de caso, dividindo a exposição em torno das três fases que identificamos na relação das feministas políticas com os partidos: incorporação, ruptura e aliança, subdividindo essa última em aliança instrumental e aliança por projeto. Por fim, na terceira parte, "A modularidade da autonomia e a zona de interseção", apresentamos a análise do caso.

\section{A relação entre movimentos sociais e partidos políticos}

A agenda do contentious politics ou confronto político (McAdam, Tarrow e Tilly, 2001; Tilly, 2008) tem conduzido a uma renovação no campo de estudos dos 
movimentos sociais ao afirmar o nexo constitutivo entre política institucional e política contestatória. Para o que nos interessa aqui mais diretamente, esse pressuposto se desdobra na compreensão dos movimentos sociais a partir das complexas redes políticas e institucionais nas quais estão inseridos e sobre as quais atuam no esforço de produzir mudanças. A afirmação de que os movimentos sociais não jogam sozinhos e de que as instituições políticas importam para compreender seus resultados pode parecer banal, mas tem decisivas implicações na construção das agendas de pesquisa.

A primeira implicação é a redefinição do foco da pesquisa. A ênfase se desloca dos movimentos sociais per se para a análise das relações que eles estabelecem com uma variedade de atores, como políticos eleitos, burocracia pública, partidos, meios de comunicação, público espectador ou outros movimentos. A segunda implicação consiste em levar adiante a ideia de que os movimentos sociais são agentes de mudança que são afetados e podem afetar o jogo da política institucional. Ou seja, movimentos sociais e política institucional são vistos como mutuamente constitutivos ${ }^{2}$. Uma terceira implicação relevante é a consideração do contexto político da interação. Trata-se de uma abordagem que busca no contexto político as razões para a emergência, o desenvolvimento e os resultados alcançados pelo movimento. Um debate central no interior da abordagem é até que ponto essa ênfase sobre as condições exteriores da luta, importante para evitar o voluntarismo da análise, não levaria a uma visão determinista segundo a qual os movimentos apenas reagiriam às ameaças e oportunidades do contexto (Goodwin e Jasper, 1999; Polletta, 1999). Essas críticas têm resultado no reconhecimento dos elementos subjetivos e processuais que medeiam oportunidade e ação e explicam a mobilização e seus resultados, assim como na discussão sobre como as oportunidades variam de ator para ator e em função das demandas e dos resultados pretendidos (Kriese, 2004; Amenta e Halfmann, 2012).

No que se refere especificamente à relação entre movimentos sociais, partido e Estado, a abordagem do confronto político permitiu questionar a visão corrente na literatura segundo a qual a aproximação dos movimentos com o Estado e os partidos resultaria, necessariamente, em cooptação ou desmobilização. Recusando essencialismos, a abordagem convida a um exame da diversidade empírica dessas relações, apontando para a construção de tipologias. Nessa mesma toada, a afirmação dos movimentos sociais como outsiders que desde fora pressionam o sistema político, presente nas primeiras formulações da teoria do processo político, foi cedendo lugar a uma análise mais nuançada à medida que o repertório de ação dos movimentos incluía cada vez mais a atuação por dentro do Estado e no interior dos partidos ${ }^{3}$, ou seja, uma combinação de estratégias insider e outsider. As coletâneas from contention to

\footnotetext{
2 Esse pressuposto tem orientado, principalmente, pesquisas que exploram o nexo constitutivo entre movimentos sociais e políticas públicas, como em Meyer, Jenness e Ingram (2005).

3 De certa forma, o processo de institucionalização das demandas dos movimentos ao longo dos anos de 1990, abordado por Meyer e Tarrow (1998), contribuiu para essas revisões teóricas.
} 
democracy (Giugni, McAdam e Tilly, 1998) e States, parties and social movements (Goldstone, 2003), são bons exemplos da aplicação dessas linhas gerais a casos concretos.

Na América Latina, a relação entre movimentos sociais e instituições políticas foi tradicionalmente abordada a partir do debate da autonomia. Os processos de formação do Estado, os padrões clientelistas de relação Estado-sociedade e o contexto ditatorial que faziam do Estado o inimigo a ser combatido ajudam a explicar essa centralidade 4 . Afirmar a autonomia em relação às instituições políticas estava intrinsecamente associado, naquele momento, à própria identidade dos movimentos como novos sujeitos políticos da mudança. Não se tratava apenas de um discurso, mas de uma orientação para a ação com implicações para a formulação de estratégias. Contudo, o exercício e o aprendizado dessa autonomia se davam em um contexto altamente complexo. Em face da ausência de um Estado de bem-estar, os movimentos precisavam atuar para garantir o acesso e a democratização das políticas públicas, o que implicava a interação cotidiana com agentes estatais, políticos eleitos e representantes partidários, nas ruas e nos gabinetes. É nesse sentido que se afirma que as relações entre movimentos sociais e instituições políticas na América Latina caracterizam-se por uma tensão intrínseca entre os princípios da autonomia e da eficácia política, essa última entendida de forma restrita como acesso às políticas do Estado (Tatagiba, 2009).

O problema é que parte da literatura tendeu a tomar a autonomia como uma essência ou um dever ser dos movimentos, esvaziando sua natureza conflitiva, histórica e relacional. Judith Hellman, em um texto curto escrito em 1992 e intitulado "The study of new social movements in Latin América and the question of autonomy", denuncia o que ela chamou de "fetichismo da autonomia" dos cientistas sociais latino-americanos, que, a partir de certo purismo, interpretaram a aproximação com a política institucional sob o signo da subordinação ou cooptação do movimento.

Given their preference for wholly autonomous movements, these analysts see the incorporation of an independent neighborhood group into a broad Socialist workers' movement as a result every bit as disappointing as cooptation by the state or Absorption into a personal network. In either or any case, something pure and wonderful (a popularly based, grass-roots movement) disappears and is replaced by something less desirable (Hellman, 1992).

Desarmando o argumento da "oposição natural" e da força inversamente relativa (movimentos serão mais fortes quanto mais fracos forem os partidos), Hellman defende

\footnotetext{
${ }^{4}$ Como destacado pela Teoria dos Novos Movimentos Sociais, o discurso autonomista também esteve no centro das reivindicações dos novos movimentos sociais europeus e americanos no ciclo de protestos dos anos de 1960. Contudo, a partir de uma associação discursiva e estratégica distinta quando comparada ao significado que essa reivindicação assume nas democracias do sul. A base social presente nos protestos, a configuração do Estado e a natureza das demandas respondem pelas principais diferenças, como analisa Davis (1999).
} 
que a coalizão entre partidos e movimentos de esquerda pode não só favorecer seu desenvolvimento recíproco - afinal, como ela diz, "the encounter between movement and party is a dialectical one in which the movement is altered but so, too, is the party" (Hellman, 1992, p. 59) - mas se configurar, em conjunturas determinadas, em estratégia fundamental para o avanço da democracia na região.

Em meados dos anos 1980, alguns analistas brasileiros também já apontavam as consequências negativas desse "fetichismo da autonomia" sobre a conformação da agenda de pesquisa na área e expunham sua inadequação diante de uma realidade na qual a decisão dos movimentos sociais de intervir na disputa política os levou inclusive a criar um partido, o Partido dos Trabalhadores, e a ensejar no cotidiano das lutas nas periferias distintas formas de relação com as agências estatais, ainda no contexto da ditadura (Santos, 1981; Cardoso, 1987, 1994; Boschi e Valladares, 1983; Kowarick, 1987; Jacobi, 1989). Com a abertura democrática e a maior permeabilidade do Estado, essa atuação institucional se intensificou, com o forte envolvimento dos movimentos na criação de novos espaços de participação no interior do Estado, a ocupação de postos na burocracia pública e a atuação nas eleições em favor de candidatos aliados ou lançando candidatos dos próprios movimentos. A presença do Partido dos Trabalhadores facilitava essa atuação institucional, principalmente quando o Partido se tornava governo. Nesse novo contexto, o desafio da análise estava em compreender como os movimentos sociais produziam mudanças em contextos democráticos e de que forma esse contexto impactava os movimentos. Uma agenda para a qual Alvarez e Escobar chamaram a atenção em sua importante antologia sobre os movimentos sociais na América Latina:

As students of social movements, we must direct our attention to the terrain of formal democratic institutions because it now intersects the terrain of quotidian politics so crucially expanded by social movements during the 1980s. Analyses of democratic consolidation would similarly be enhanced if we shifted our theoretical gaze to examine the nexus of institutional and extrainstitutional democratic practices at both the local and national levels (Alvarez e Escobar, 1992, p. 328-329).

A abordagem da construção democrática (Alvarez, Dagnino e Escobar, 2000; Dagnino, 2002; Dagnino, Olvera e Panfichi, 2006) contribui para o avanço dessa agenda ao colocar em primeiro plano a atuação dos atores sociais na esfera político-institucional e defini-la não mais como uma perversão da "verdadeira natureza" dos movimentos, mas como uma dimensão importante da luta pela democracia. O conceito de "projeto político" e o mecanismo do "compartilhamento de projetos políticos", presentes na produção de Dagnino e seus colegas, ajudaram a promover uma inflexão no debate sobre a autonomia em direção a uma abordagem mais relacional e a uma concepção menos determinista das fronteiras entre sociedade civil e sociedade política. A hipótese central da abordagem é que, em cenários marcados pela carência de acesso a direitos básicos de 
cidadania, os movimentos sociais podem fortalecer a democracia à medida que ampliam o escopo de suas ações em direção ao plano político institucional (Dagnino, Olvera e Panfichi, 2006, p. 37-38).

O left turn em vários países na região precipitou uma nova onda de estudos sobre os movimentos sociais e suas relações com o campo político institucional, principalmente a partir de sua atuação junto aos novos governos de esquerda ${ }^{5}$. No caso brasileiro, a presença do PT no governo federal resultou na intensificação do trânsito de militantes para dentro do Estado (D'Araújo, 2007), com implicações sobre as formas de produção das políticas públicas, a configuração dos movimentos e os padrões tradicionais de relação entre Estado e sociedade - esse intenso trânsito de ativistas entre as fronteiras do Estado e da sociedade foi o foco central do artigo de Abers e Von Bülow (2011). Nessa mesma chave, Silva e Oliveira (2011), na sua análise sobre o movimento de economia solidária no Rio Grande do Sul, mostram como a organização e a atuação dos movimentos não só não se dão externamente ao Estado, como são fomentados pela interação com os agentes e as políticas governamentais, por meio da mediação com os partidos. Compartilhando desses pressupostos gerais, várias pesquisas têm buscado compreender a implicação dessas mudanças nas formas de participação da sociedade (Teixeira, 2013; Abers, Serafim e Tatagiba, 2014; Dagnino e Teixeira, 2014) e nos processos de elaboração e implementação de políticas públicas ${ }^{6}$. A imbricação entre a lógica partidária e os novos mecanismos de participação e representação instituídos no Brasil ao longo das últimas décadas foi também objeto de investigação em Tatagiba e Blikstad (2011) e Gurza Lavalle, Romão e Zaremberg (2014). Mais recentemente, o próprio tema da autonomia voltou ao centro do debate, a partir de uma revisão conceitual orientada pela ótica da mútua constituição entre o Estado e a sociedade civil, em que a autonomia é apresentada não mais como categoria normativa, e sim como resultado da experiência: "longe de ser ausência de interação com atores políticos, a autonomia como categoria nativa exige o escrutínio dos modos práticos de sua inovação nas, e por meio das, configurações concretas em que ela é mobilizada" (Gurza Lavalle e Szwako, 2015, p. 182).

Contudo, apesar dos avanços teóricos e metodológicos presentes nessas pesquisas e das evidências empíricas que esses estudos nos trazem de que o partido importa para

\footnotetext{
5 Já temos uma vasta produção sobre o tema, em vários países latino-americanos, a partir inclusive do estímulo de centros de pesquisa como Clacso e Flacso. Uma tarefa que fica para pesquisas futuras é a análise do conjunto dessa produção, a partir desse olhar sobre as relações entre movimentos sociais e política institucional. Para uma exemplificação dessa vasta produção, mencionamos: Arnson e Perales (2007), Tatagiba (2009), Madrid e Hunter (2010), Zibechi (2011), Cannon e Peadar (2012), Castro, Koonings e Wiesebron (2014), Dagnino e Teixeira (2014), Abers, Serafim e Tatagiba (2014) e Coraggio e Laville (2014).

${ }^{6}$ Para alguns exemplos de estudos com ênfase sobre o nexo movimentos sociais e políticas públicas no plano federal, citamos: Abers e Oliveira (2015) e Losekann (2009) (meio ambiente); Serafim (2013) e Tatagiba e Teixeira (2016) (política habitacional e urbana); Gutierres (2015) (assistência social); Dowbor (2012) (saúde); Ferro (2010) (população de rua); Leitão (2012) (política racial); Penna (2015) (reforma agrária).
} 
a forma e os resultados dessas relações, esse tema não tem recebido uma análise mais sistemática e segue subteorizado.

Com este artigo pretendemos contribuir para responder a essa lacuna, a partir da análise da relação entre o movimento feminista e o sistema de partidos na Nicarágua. Nossa contribuição ao debate teórico advém dos problemas que tivemos que enfrentar na empiria. O primeiro problema diz respeito à questão da autonomia. Quando iniciamos a pesquisa, não tínhamos intenção de abordar esse tema de forma mais sistemática. Afinal, partilhávamos de uma agenda que nos levava a pensar em fluxos, trânsitos e relações e não em fronteiras, essências ou características distintivas entre os campos. Mas o tema da autonomia se impôs como problema incontornável, como ficará evidente ao leitor na apresentação do caso. Nossa tarefa foi, então, recolocar em jogo o debate da autonomia sem incorrer nos fetichismos e purismos que marcaram a produção pretérita. A reflexão teórica acerca da modularidade da autonomia foi o caminho que encontramos para responder a esse desafio. O segundo desafio refere-se a uma particularidade do nosso caso: o fato de o Movimiento Autónomo de Mujeres (MAM) ter estabelecido uma aliança formal com o partido, o Movimiento de Renovación Sandinista (MRS), com o objetivo de influenciar a disputa política eleitoral, e um eventual governo, a partir de uma agenda de gênero. As dinâmicas e os resultados da aliança tiveram impactos mútuos sobre os atores, partido e movimento, e sobre o contexto político de forma mais ampla. As ferramentas conceituais que tínhamos à nossa disposição (múltipla filiação, compartilhamento de projeto político, brokerage, trajetória, dentre outros) eram úteis para explicar os mecanismos pelos quais os atores teceram os vínculos partidomovimento, mas não ajudavam a compreender o que acontecia depois que os atores decidiram coordenar suas ações. Ou seja, nosso desafio era tematizar de que forma o nexo partido-movimento produzia mudança. Para isso, forjamos o framework analítico da zona de interseção. Na última parte do artigo, vamos elaborar com mais vagar as nossas reflexões analíticas em torno dessas duas ideias: a modularidade da autonomia e a zona de interseção. Antes, porém, vamos apresentar o nosso caso.

\section{A relação entre o movimento feminista e o sistema de partidos na Nicarágua (1974-2012)}

A relação entre o movimento feminista e os partidos na Nicarágua pode ser dividida em três fases: incorporação (de 1974 a 1989), ruptura (de 1990 a 2000) e aliança (de 2001 a 2012). Nesse item vamos percorrer esses momentos, nos detendo com mais vagar na última fase, em que perscrutamos a aliança entre MAM e MRS, com o objetivo de apreender sua dinâmica e seus impactos. 


\section{A incorporação (1974-1989)}

Com a revolução sandinista de $1979^{7}$, a Nicarágua transformou-se em um símbolo da "dimensão global de resistência" (Molyneux, 2001), com destaque para o papel desempenhado pelas mulheres no movimento guerrilheiro (1961-1978). Segundo Molyneux, a guerrilha nicaraguense da FSLN incorporou entre $25 \%$ a $30 \%$ de mulheres nas revoltas, o maior contingente de mulheres numa revolução armada, com exceção do Vietnã (Molyneux, 2001, p. 38). A presença das mulheres encontrou expressão no "Programa Histórico da FSLN", emitido em 1969, que dedicou um capítulo completo à "emancipação da mulher", no qual estabelece a necessidade de estender os direitos para os filhos de mães solteiras, creches para crianças de mães trabalhadoras, igualdade econômica e política entre homens e mulheres, entre outros direitos relacionados, evidentemente transgressores para a época ${ }^{8}$. Contudo, apesar da significativa presença na base, foi só a partir de 1974 que as mulheres começaram a ganhar destaque nas ações armadas contra a ditadura, inclusive ocupando postos de liderança em missões célebres ${ }^{9}$.

Fora do campo de batalha, as mulheres também se organizavam para o combate à ditadura em um conjunto amplo de iniciativas. Foi nesse contexto que, em 1978, por iniciativa de uma das tendências da FSLN (a Tendência Proletária) ${ }^{10}$, foi criada a Asociación de Mujeres ante la Problemática Nacional (Ampronac), considerada a gênese do movimento feminista nicaraguense. O objetivo era aglutinar mulheres urbanas de classe média no apoio humanitário aos presos políticos. Com o tempo, a Ampronac ampliou suas bases sociais, incorporando camponesas e trabalhadoras, e diversificou suas ações de resistência à ditadura.

Com o sucesso do movimento guerrilheiro e a implantação do governo revolucionário (1979-1989), a FSLN passou a atuar num contexto político altamente complexo. Após 45 anos de governo ditatorial e mais de cinco anos de conflito armado, o país estava em colapso. Para os esforços da reconstrução, a FSLN aumentou o controle sobre as organizações de massa (sindicatos, docentes, associações de profissionais e mulheres) com as quais mantinha relações consolidadas desde o período insurrecional,

\footnotetext{
${ }^{7}$ A revolução da Nicarágua, comandada pela frente guerrilheira Frente Sandinista de Liberación Nacional (FSLN), teve seu maior ciclo de confronto armado entre 1976 e 1979. A Revolução marcou o fim da ditadura somozista que se instaurara desde 1936, a partir do golpe militar protagonizado pelo então chefe do Exército, Anastasio Somoza García (assassinado em 1956). A ditadura somozista se caracterizou por uma dinastia de duas gerações da família Somoza. Para detalhes do regime instaurado naqueles anos, recomenda-se Marega (1982), Zimmermann (2006) e Puig e Close (2012).

8 O Programa Histórico completo da FSLN pode ser consultado diretamente em: <http://americo.usal.es/oir/opal/Documentos/Nicaragua/FSLN/PROGRAMA\%20HISTORICO\%20DEL\%20FS LN.pdf>. Acesso em: 20 maio 2016.

9 Para conhecer mais sobre os operações militares da guerrilha sandinista, recomenda-se a plataforma virtual de Mónica Baltodano: <https://memoriasdelaluchasandinista.org/>.

${ }^{10}$ A despeito do alto nível de centralização e disciplina militar, o movimento guerrilheiro foi conformado por três facções (ou tendências) articuladas ao redor do fim da ditadura militar, mas divididas quanto às estratégias de luta armada (Baldizón, 2004).
} 
submetendo suas agendas à "agenda da revolução". No caso das mulheres, isso significou a desintegração da Ampronac e a criação de uma nova associação - a Asociación de Mujeres Nicaraguenses Luisa Amanda Espinoza (AMNLAE) ${ }^{11}$ completamente submetida ao controle do partido de vanguarda. A AMNLAE reproduz a visão original do papel das mulheres na revolução e concentra sua atuação no trabalho com as "mães dos heróis" (os jovens mortos na luta insurrecional ou no confronto armado contra a contrarrevolução dos anos 1980) nos bairros periféricos. As profissionais liberais, trabalhadoras agrícolas e jovens rapidamente perceberam que seus interesses não seriam representados pela nova organização e que seria necessário buscar alternativas que Ihes garantissem influência política.

A orientação da FSLN para que as duas principais centrais sindicais do setor público, a Central Sandinista de Trabajadores (CST) e a Associación de Trabajadores del Campo (ATC), criassem Secretarias de Mulheres abriu o espaço que as mulheres precisavam para redefinir sua atuação no campo político. Em entrevista, uma das líderes do movimento explica a estratégia de dirigir a atuação em direção aos sindicatos:

Entonces, nuestra estrategia era ésa, porque las centrales sindicales y las organizaciones de masas tenían más fuerza política que AMNLAE. Más poder político. La idea era subirse a ese caballo porque ese era el ganador, y al mismo tiempo influenciar a AMNLAE desde dentro pero por fuera (Ana Criquillon, feminista francesa residente na Nicarágua, entrevista realizada em janeiro de 2012).

Nos sindicatos, as mulheres experimentaram um ativismo mais autônomo, graças à influência das feministas europeias (principalmente francesas e espanholas) que chegaram à Nicarágua atraídas pelo projeto revolucionário. Em pouco tempo, as jovens Secretarias das Mulheres de ambas as centrais sindicais começaram a implementar uma série de projetos como a criação de clínicas de saúde sexual e reprodutiva para atender as trabalhadoras agrícolas, creches que funcionavam especialmente nos períodos de colheita de café e algodão, assim como o desenvolvimento de uma série de cursos de formação em feminismo e mundo laboral ministrados por estudiosas espanholas. Esse acúmulo se traduziu na participação das mulheres na Assembleia Constituinte, em 1986, na qual conseguiram aprovar o divórcio unilateral e o reconhecimento de direitos de união estável, de um pacote mais amplo que incluía temas como a criminalização da violência contra as mulheres, o direito da mulher sobre seu próprio corpo e as punições aos assédios no mundo laboral.

Essa nova consciência feminista, principalmente das mulheres das centrais sindicais, gerou conflitos com a FSLN, que acusava as mulheres de promoverem uma "batalha dos sexos" (Murguialday, 1990, p. 193-204), contrária aos interesses das classes trabalhadoras. O conflito com a FSLN levou as mulheres a buscar novas formas

${ }^{11}$ O nome era uma homenagem à primeira ativista da FSLN, assassinada em 1970. 
organizacionais para representação dos seus interesses. As feministas das cidades do interior do país, que não se sentiam representadas na AMNLAE e nem nas Secretarias da Mulher das centrais sindicais, começaram a criar os primeiros coletivos de mulheres nos territórios $^{12}$. Enquanto isso as feministas políticas, vinculadas ao sindicato e à AMNLAE, tiveram a ideia de criar um novo partido, o Partido de la Izquierda Erótica (PIE) $)^{13}$. A ideia não foi adiante, mas o recado estava dado, como disse uma das entrevistadas: "havia uma força feminista acumulada que começava a se notar fora do controle da FSLN" (Ana Criquillon, entrevista realizada em janeiro de 2012).

Portanto, durante o período insurrecional, a FSLN estimulou o ativismo das mulheres, ao mesmo tempo em que buscou mantê-lo sob o seu controle, submetendo as demandas de gênero às causas da revolução. A incorporação das mulheres ao sistema político, via partido e centrais sindicais, Ihes conferiu ganhos, mas adiou o problema da construção de formas organizacionais próprias. Como explica Sara Henríquez, uma das líderes do Coletivo de Mulheres de León, no ocidente do país:

ésta fue una revolución de machos. Una cosa es la lucha revolucionaria, en donde las mujeres nos vamos a pelear contra una dictadura y ese era el objetivo. Ese fue el foco, siempre tuvimos claro de que nuestro objetivo era derrocar al dictador, pero sobre un montaje patriarcal. ¿Qué cambio ibas a pedir, si todo venía de los machos y cuántos abusos no se cometieron? La revolución también fue eso. Las mujeres no teníamos conciencia de género, ni teníamos bien claro lo del feminismo. Yo me acuerdo que esto lo aprendí después de la revolución. Eso requirió mucha educación, pero los estudios de género son demasiado recientes. En definitiva, la revolución fue macha (Sara Henriquez, entrevista realizada em abril de 2013).

A ruptura (1990 a 2000)

A partir das negociações regionais na América Central, reforçadas com uma declaração nacional de cessar-fogo com a contrarrevolução, o governo da FSLN convocou novas eleições presidenciais, em fevereiro de 1990, nas quais foi estrondosamente derrotado por uma coalizão de 14 partidos de oposição, a maioria deles de direita e centro-direita. Como líder da coalizão, Violeta Chamorro venceu as eleições e governou o país entre 1990 e 1996. A voz das mulheres teve certo peso no comportamento eleitoral

\footnotetext{
12 Os coletivos de mulheres foram espaços criados por feministas locais que pretendiam experimentar novas formas de organização mais próximas das comunidades, particularmente oferecendo serviços às mulheres nos pequenos municípios, mas também experimentando novas formas de feminismo local. É nesse contexto que surgem os coletivos de mulheres de Matagalpa (norte), Masaya (sul) e León (ocidente), totalmente independentes das orientações sandinistas e da intermediação de AMNLAE.

${ }^{13}$ O PIE não se consolidou como partido político, nem providenciou o registro no Conselho Eleitoral. Porém, o fato de a iniciativa ter surgido (tiveram reuniões e uma assembleia) no meio de um contexto de centralização e controle da FSLN sobre todas as organizações revela o nascimento de uma vocação autonomista e partidária que distingue o movimento feminista atualmente.
} 
de 1990. Como Bab (2012) confirmou anos mais tarde, a maioria dos eleitores de Chamorro foram mulheres, provavelmente mães ou companheiras de homens jovens que tinham sido assassinados, ou no mínimo mobilizados compulsoriamente no Serviço Militar Patriótico (SMP) durante os anos do conflito armado em reação à contrarrevolução. Como primeiro governo eleito após anos de conflito armado, Chamorro tinha diante de si tarefas altamente complexas: a construção da nova institucionalidade democrática, o processo de pacificação após anos de confronto e uma mudança radical de sistema socialista para uma economia de livre mercado (Cuadra e Jimenez, 2010).

Nos flancos sandinistas a vitória eleitoral de Chamorro foi vivida com um sentimento de derrota e luto, com implicações para o conjunto das organizações que se envolveram na resistência armada (Kampwirth, 2006). No caso específico do feminismo, esse foi o momento de afirmação da autonomia como ruptura com a FSLN e com o Estado neoliberal. Assim, para as feministas esse contexto trouxe muitas ameaças, mas também algumas oportunidades.

A perda de poder da FSLN permitiu uma consolidação da consciência feminista entre as mulheres organizadas e com isso multiplicaram-se cursos de formação e oficinas com temas específicos para mulheres, gerando novas redes e alianças. Diferente da base sandinista, que perdia vigor e legitimidade social, o feminismo encontrou notável desenvolvimento no período. Não surpreende, portanto, que, apesar do desconhecimento do governo de Violeta Chamorro de uma série de direitos das mulheres que ficaram estabelecidos na Constituição de 1986, as feministas tenham conseguido importantes conquistas entre 1992 e 1997, tais como a instauração de Delegacias da Mulher em todas as instâncias policiais do país, Programas de Atenção à Saúde da Mulher e apoio jurídico às operárias da Zona Franca.

Em 1992, as mulheres anunciaram a "declaração de autonomia", um documento que tinha por objetivo publicizar sua separação da FSLN e do governo de Chamorro. Para concretizar essa autonomia era preciso criar organizações próprias, e dois modelos se apresentavam como alternativa, ambos experimentados na fase anterior. Por influências das feministas europeias, que já começavam a providenciar projetos de cooperação internacional para as primeiras organizações descentralizadas, os coletivos locais sugeriram a formação de redes, descentradas e reticulares, que se instaurariam ao redor da agenda temática das mulheres. Ao contrário dos coletivos locais, as feministas políticas defendiam um modelo de entidade única nacional, com comando centralizado e vertical, como experimentado na revolução. Após várias semanas de debates internos, as feministas optaram pelo formato de redes, instituídas em quatro frentes: Red Salud (RS), Red de Mujeres Contra la Violencia (RMCV), Red de Derechos Económicos de las Mujeres $\left(\right.$ RDEM) e Red de Educación No Sexita (RENS) ${ }^{14}$. Tanto a decisão pelo modelo de redes

\footnotetext{
${ }^{14}$ Das quatro estruturas, apenas duas foram duradouras no tempo. A RS manteve uma forte atuação ao longo dos primeiros cinco anos, mas com o tempo foi se decantando numa atuação de ONG e atualmente tem a responsabilidade de coordenar a campanha 28 de setembro no país (a campanha latino-americana
} 
quanto a realização do Festival do $52 \%{ }^{15}$, conhecido como o "Encontro Unidas en la Diversidad, UED", constituíram o lançamento do movimento feminista da Nicarágua como é conhecido nos dias de hoje, ou seja: um movimento organizado em redes, altamente plural e reclamando sua autonomia do sistema político.

Mas o ideal de uma organização única continuou no horizonte das feministas políticas que, em 1992, acabaram por criar o Comité Nacional Feminista (CNF) ${ }^{16}$. Maria Teresa Blandón, uma das fundadoras dessa estrutura, explica a lógica que estava por detrás de sua criação:

Nos fuimos a fundar el CNF porque nos hacía falta algo. Estaban las redes, perfecto, pero eran redes temáticas que estaban sobre un tema específico. Nosotras queríamos tener un debate más nacional, queríamos hablar de lo que pasaba en la coyuntura política, en el Estado, en los partidos. Es decir, queríamos tener un foro de mujeres feministas, un activismo con más reflexión, teorización y más propuesta y por eso creamos el CNF (Maria Teresa Blandón, entrevista realizada em maio de 2013).

Nesse período, a FSLN enfrentava o desafio de definir as estratégias mais eficientes para fazer oposição ao governo de Violeta Chamorro e reconquistar o poder. $O$ debate gerou duas tendências. De um lado, a chamada "Esquerda Democrática", defendida por Daniel Ortega, que privilegiava o uso de um repertório conhecido baseado no enfrentamento nas ruas e na violência como forma de desestabilizar o novo governo. De outro lado, a corrente "Por um Sandinismo que volte às Maiorias", que pressionava por estratégias de oposição institucional a partir do diálogo e de alianças dentro do sistema de partidos e com as elites locais, em nome do "novo jogo democrático" (Santiuste, 2001; Luciak, 2001). O conflito entre as tendências se intensificou a ponto de gerar uma cisão interna na FSLN, da qual surgiu o Movimiento de Renovación Sandinista (MRS) em 1995. A saída dos dissidentes cedeu amplo espaço para as transformações partidárias, segundo os interesses de Ortega ${ }^{17}$. É nesse ponto que a FSLN começa a se transformar em "Orteguista".

A cisão da FSLN teve impacto negativo nas redes internas das organizações de massas, que viveram a tensão praticamente na mesmo grau. Os sindicatos se fracionaram e algumas líderes feministas dentro desse setor foram acusadas de traição

pela legalização do aborto). A RMCV é a única estrutura que ainda hoje aglutina as organizações locais e mantém uma atuação beligerante no nível local. Faz total sentido, como veremos na seção "A modularidade da autonomia e a zona de intersecção", no contexto em que não apenas a violência aglutina as atoras em ações coordenadas, mas permanece presente uma disputa entre as feministas e o novo Estado sandinista, ao redor da falta de resposta oficial ao incremento dos femicídios no país.

15 O nome do festival é uma referência ao percentual de mulheres que compõem a população da Nicarágua.

${ }^{16} \mathrm{O}$ CNF e a Red de Mujeres Contra la Violencia (RMCV) foram as principais redes feministas no país, entre 1995 e 2004, no caso do CNF com interrupções ao longo do período.

17 Existem poucos estudos que tratam da transformação da FSLN após a perda das eleições de 1990 e o fim do período revolucionário, sendo importantes exceções os trabalhos de Santiuste (2001), Baldizón (2004) e Luciak (2001). 
por parte dos companheiros sindicalistas. Na visão deles, repetindo o discurso da primeira fase, ser feminista não só "distraía" da questão central de classe, mas também implicava não reconhecer a liderança tradicional e histórica da FSLN, "da mesma forma que o fazia o MRS". Com a ruptura partidária, as militantes do movimento foram impelidas a tomar posição e muitas foram expulsas da FSLN, em alguns casos perseguidas judicialmente.

Portanto, o clima já era de profundo desgaste quando Ortega - já sendo o maior líder da FSLN e da oposição dentro do Congresso Nacional - foi acusado de estupro pela sua enteada Zoilamérica Narváez, em 1998, e abre-se um processo judicial. O caso Zoilamérica é um "divisor de águas" para o movimento feminista. Durante a pesquisa de campo, várias das entrevistadas definiram esse momento como de "incisão vital", isto é, o corte que restava para a separação definitiva com o partido.

Apesar dessa ruptura, é importante considerar que, principalmente no caso das feministas políticas, a relação com a FSLN - agora uma relação de enfrentamento segue balizando suas escolhas estratégicas e se desdobra em questões que vão além da agenda de gênero, remetendo à dimensão identitária do "ser sandinista". Desde o seu nascimento, a FSLN foi associada a um projeto de nação em um momento muito particular. Apostar no sandinismo, pós-derrubada da ditadura, significava mobilizar os anseios de um projeto nacional democrático, equitativo e orientado pela justiça social do qual carecia a ditadura somozista. Dessa forma, o sandinismo assumia uma dimensão histórica, coletivamente apropriada e que transbordava os limites partidários. Mas com o fracasso do projeto revolucionário em 1990, a FSLN se transformou em mais uma expressão (importante é claro, mas não mais a única) do sandinismo. Assim ao longo dos anos de 1990 e 2000, o ser "sandinista" manteve esse sentido forjado na luta, disputando a hegemonia pretendida por Ortega, hoje no poder. A aliança do movimento feminista com o MRS exprime também essa disputa pelo legado do sandinismo que concretamente passa a se traduzir na oposição ao projeto de poder de Daniel Ortega, que, na visão do MAM- MRS, foi quem traiu a causa sandinista original.

\section{Aliança (2001-2012)}

Em 2001 houve novas eleições e as feministas políticas e o MRS buscaram alternativas para incidir no pleito. O MRS tentou uma reaproximação com a FSLN com o objetivo de atuar conjuntamente em uma única coalizão sandinista, mas as negociações fracassaram não só pelas imposições de Ortega quanto às candidaturas a deputados, mas também pelo pacto liberal-sandinista ${ }^{18}$. Já as feministas políticas, por meio do

\footnotetext{
${ }^{18}$ Para bloquear o andamento do processo na Justiça, surgido pela acusação por estupro, Ortega negociou uma série de emendas à Constituição e à Lei Eleitoral com o então presidente liberal Arnoldo Alemán (1996-2001) e em troca não levaria adiante as acusações de corrupção que a FSLN iniciara contra o mandatário pelo desvio da ajuda internacional que respondeu à devastação provocada pelo furacão Mitch, o maior fenômeno natural que arrasou uma boa parte da América Central nos últimos meses de 1998. No
} 
Comitê Nacional Feminista, fizeram um primeiro ensaio de aliança junto a uma coalizão de partidos para atuar nas eleições presidenciais daquele ano. Contudo, a aliança se rompeu no momento da seleção das candidaturas, diante do veto das feministas a alguns nomes indicados. Quem venceu a eleição presidencial foi Enrique Bolaños (2002-2006), do Partido Liberal Constitucionalista.

A condução das políticas sexuais e reprodutivas levou a vários conflitos entre as feministas e o governo de Bolaños, de 2003 a 2004. Destaca-se, nesse sentido, o conflito com o Ministério da Família em função da condução de um caso de estupro, que ganhou forte repercussão na mídia, o "caso Rosita" ${ }^{19}$, e os embates com o Ministério da Educação por causa da produção de uma cartilha escolar para a formação em sexualidade, totalmente orientada por fundamentos religiosos. Para enfrentar esse contexto adverso as feministas criam o Movimiento Autónomo de Mujeres, o MAM, em 2006, após um conjunto de discussões na rede do movimento, organizado pelo Comité Nacional Feminista (CNF).

Ao longo de 2004-2005, o Comité Nacional Feminista convocou uma série de encontros que, com o tempo, adquirem o status de "mesa de concertação", cujo grande objetivo era realizar quatro grandes fóruns nacionais. No IV Fórum, realizado em fevereiro de 2006, a Red de Mujeres Contra la Violencia e o Comité Nacional Feminista decidiram que a "mesa de concertação" deveria progredir para uma "coordenadoria" do feminismo nacional, estruturando o que as feministas começavam a chamar de "movimento autônomo". Ainda em fevereiro, elas divulgaram o "Documento Político", que dava forma organizacional à "refundação do movimento autônomo", criando assim o Movimiento Autónomo de Mujeres (MAM). A intenção declarada no Documento era enfrentar, por meio do MAM, o pacto liberal-sandinista e eleger um governo mais sensível às demandas do movimento de mulheres. Ao longo do "Documento Político" as feministas definem o MAM como um "movimento social" e um "movimento político" (Documento Político, p. 14-15 e p. 29-30), que deveria focar sua atuação no âmbito público.

acordo, Alemán obteria, automaticamente, um assento no Legislativo uma vez concluído o seu mandato e Ortega conseguiria reduzir a porcentagem de votos estabelecidos na Constituição para declarar o triunfo eleitoral em primeiro turno. Tal negociação, que, entre outras emendas, estabeleceu empecilhos para partidos pequenos participarem nas disputas eleitorais, foi conhecida como "o pacto liberal-sandinista" (Baldizón, 2004).

19 O caso envolve o estupro, seguido da gravidez, de uma menina de 9 anos, filha caçula de imigrantes nicaraguenses na Costa Rica, nas plantações de cana onde a sua família trabalhava durante o período de colheita. O caso complicou as relações bilaterais, já gastas, entre ambos os países e gerou uma polêmica nacional entre todos os setores que debatiam se a menina devia ou não abortar. Depois de uma profunda exposição pública, as organizações da Red de Mujeres contra la Violencia, RMCV, conseguiram ajuda para que, em total sigilo, um grupo de médicos realizasse o aborto sem informar à mídia. $O$ Estado acusou as nove feministas da RMCV de terem sequestrado a menina e conduziram o caso penalmente. Para o movimento de mulheres, esse caso era uma retaliação da FSLN pelo apoio que a RMCV deu à Zoilamérica, na acusação de estupro contra Ortega, em 1998. O caso Rosita na Nicarágua não foi só um símbolo nacional da luta do movimento de mulheres pela legalização do aborto, como chamou a atenção do feminismo latino-americano sobre a aliança dos Estados neoliberais com posições fundamentalistas, representadas na hierarquia católica e evangélica, para regredir em direitos sexuais na região. 
A criação do MAM foi um momento de inflexão para o feminismo nicaraguense ao criar uma rede única capaz de conduzir, de forma articulada, uma das estratégias centrais do movimento que era incidir no sistema político a partir da reforma do Estado e da democratização e modernização dos partidos políticos. A avaliação é que essas eram pautas "legitimamente feministas" e que uma estrutura centralizada poderia fazê-las avançar a partir da aliança com um "partido confiável".

\section{A aliança instrumental para as eleições}

Criado o MAM, o passo seguinte era avançar nas alianças partidárias para o processo eleitoral. As eleições de 2006 eram especiais porque nelas, pela primeira vez, o bipartidarismo que a Nicarágua vinha consolidando desde o fim da revolução sandinista se viu desafiado. Após a vitória de Violeta Chamorro, em 1990, as eleições presidenciais seguintes foram todas disputadas por duas representações bem definidas, o sandinismo (particularmente a FSLN com a candidatura de Ortega) versus partidos liberais (particularmente PLC). Mas, desde sua fundação, o MRS vinha correndo por fora e conquistando importantes prefeituras, inclusive a capital, assim como posições no Legislativo. Essa presença do MRS e a crise no flanco liberal tornaram as eleições de 2006 bastante imprevisíveis. A FSLN não apenas enfrentava seu tradicional adversário, os liberais, mas também seus antigos companheiros do MRS, com a candidatura do exprefeito de Manágua Herty Lewites, enquanto os liberais se mostraram também fragmentados, com duas candidaturas no pleito. Para a cúpula do MAM essa fragmentação partidária era uma oportunidade para incidir no pleito e voltar a ter voz no Estado.

A ruptura do MRS com a cúpula da FSLN e, depois, o seu posicionamento em defesa das feministas e contra Ortega no caso Zoilamérica pavimentaram o caminho para a aliança MAM-MRS nas eleições presidenciais de 2006. A aliança foi firmada numa espécie de contrato, com reconhecimento notarial, assinado por representantes de cada um dos atores, em um ato público celebrado em 15 de junho de 2006. O evento teve a presença do candidato Herty Lewites e, ao menos para o MRS, era um ato-chave nos meses prévios ao início da campanha eleitoral. O Documento subscrito por Sofia Montenegro, como representante da Coordenadoria Política do MAM, e Luis Carrión, em nome do Diretório do MRS, traz uma pequena exposição de motivos e cinco cláusulas que determinam o alcance e as características da aliança e estabelece funções para ambos os atores. Do lado do MRS assumiu-se a obrigação de incorporar no programa de campanha eleitoral - e de governo, no caso de um eventual triunfo - uma agenda de cinco compromissos em torno da democracia e equidade de gênero. Para o movimento, os deveres consistiam em assessorar a equipe de campanha, auditar o manejo dos fundos da campanha, apoiar os candidatos e candidatas do MRS e assessorar a bancada da coalizão no Legislativo (Acuerdo Político entre el MAM y la Alianza MRS, 2006). 
Tendo em vista o calendário eleitoral, a aliança se estabeleceu antes que o MAM tivesse costurado consensos amplos no interior da rede feminista, o que gerou inúmeras tensões e fraturas, muitas das quais persistem até hoje.

(...) ahí se da una ruptura porque por un lado hay quienes presionan por cerrar el acuerdo (con el MRS) porque pasa el tiempo y el plazo (electoral) es ya y presionan muchísimo. $Y$ hay otras que tienen una posición de que la prioridad no es tomar las decisiones por las elecciones, sino que hay que construir primero ese consenso dentro del movimiento y es ahí donde se da la primera ruptura porque el grupo decide que las que están "atrasando" esa alianza deben de salir (ser expulsas) del MAM (Geni Gomez, militante de base no território, líder do Grupo Venância, na cidade de Matagalpa, entrevista realizada em maio de 2013).

A condução da aliança também despertou uma série de questionamentos por parte da base feminista, principalmente depois que três integrantes da cúpula do MAM foram anunciadas como candidatas a deputadas dentro da coligação do MRS, sem passar pela deliberação da Assembleia Nacional do MAM. Essas tensões geraram a primeira onda de expulsões que jogou por terra a antiga aspiração das feministas políticas de contar com uma estrutura única e homogênea do feminismo nacional. As primeiras 12 expulsas do movimento, em 2006, criaram uma nova rede, o Movimiento Feminista20, que, diferente do MAM, reúne ativistas que participam em outras organizações e mantêm uma estratégia de não aproximação com os partidos políticos.

Alguns acontecimentos durante a campanha foram determinantes para a vitória de Ortega. Em primeiro lugar, a bancada da FSLN e a base governista elaboraram uma proposta para criminalizar o aborto terapêutico no seio das reformas ao Código Penal no Congresso Nacional ${ }^{21}$. Com exceção do MRS, todos os partidos políticos apoiaram a emenda. O embate entre o feminismo e o espectro conservador ao redor do aborto dominou por inteiro a campanha eleitoral. O ápice foi a passeata dos 200 mil convocada

20 Sobre o Movimiento Feminista e sua relação com o MAM, consultar Lacombe (2010) e Chaguaceda (2011).

21 Segundo nos contou uma ativista do MAM, as reformas ao Código Penal com relação ao aborto terapêutico vinham acontecendo desde 2005, quando o Legislativo estava fazendo as consultas com representantes dos partidos políticos, organizações feministas e igreja católica. O acordo alcançado, até com a igreja, estava ao redor das condicionantes para o aborto terapêutico, porém enfrentavam um impasse: a lei já permitia esse tipo de aborto em caso de estupros e riscos à saúde da mulher (com o consentimento do médico e do marido), mas a igreja não estava aceitando que se incluísse a malformação congênita como condicionante de aborto. Perante esse impasse, a FSLN ofereceu diretamente os votos para criminalizar de uma vez a figura do aborto terapêutico e esquecer o debate sobre as condicionantes. A decisão foi vendida para militantes sandinistas, inclusive para deputadas da FSLN, que tiveram que votar pela reforma, como uma estratégia para evitar que a igreja católica atrapalhasse a campanha eleitoral de Ortega, e que a reforma fosse revertida, uma vez que a FSLN ganhasse as eleições, coisa que, de fato, não aconteceu. Curiosamente, a iniciativa de criminalização foi apresentada pelo então presidente Enrique Bolaños, um idoso ultraconservador que governou o país entre 2001 e 2006. Para mais detalhes, veja "Votos vergonzantes" (El Nuevo Diario, 2006). Disponível em: <http://impreso.elnuevodiario.com.ni/2006/10/27/nacionales/32372>. Acesso em: 20 fev. 2016. 
pela Associación Pro-Vida, a hierarquia católica e a Alianza Evangélica em favor da criminalização do aborto terapêutico, em outubro de 2006. O apoio da opinião pública se reverteu em rejeição ao MRS, identificado como partido "defensor do aborto". Não bastasse, Lewites morreu de infarto quatro meses antes das votações, obrigando o MRS a lançar novo nome, sem expressão na sociedade, e rever coalizões e alianças. Na última semana de outubro, o Legislativo criminalizou o aborto terapêutico com a maioria dos votos da FSLN e da base governista de Bolaños. Dias depois, Ortega obteve a vitória eleitoral com $38 \%$ dos votos, enquanto o MRS conseguiu o apoio de apenas $5 \%$ do eleitorado nacional, colocando não mais do que três deputados no Legislativo.

A vitória de Ortega inaugurava um contexto extremamente negativo para as mulheres. Para o MRS, o saldo da disputa foi também muito negativo, com a diminuição de sua representação legislativa. Nesse contexto, ao contrário do que seria esperado, MRS e MAM decidiram não apenas manter a aliança, mas ampliar o espaço e a influência das mulheres no interior do partido. De uma aliança instrumental, ambos começaram a se orientar para uma aliança de projeto.

\section{A aliança de projeto no pós-eleições}

Embora Ortega tenha retomado o poder em 2006 com menos dos $40 \%$ do eleitorado nacional, ele não se furtou a tomar medidas duras e sem negociação com a sociedade (Puig, 2008). Ao longo dos primeiros cem dias de administração, o Executivo emitiu dois decretos para alterar o sistema de participação política, esvaziando os conselhos de participação já existentes, que contavam com a participação de ONGs e associações comunitárias que vinham experimentando relações com o Estado no lastro do processo de descentralização municipal, iniciado desde finais dos anos de 1990 (Prado, 2007). Essa restrição da arena participativa tornava ainda mais difícil o acesso ao Estado. A estratégia oficial era obstaculizar o funcionamento das organizações e movimentos sociais com os quais a FSLN desenvolvera relações de confronto, muitas vezes através da criminalização de suas atividades (Ortega Hegg, 2008), e as feministas foram um dos principais alvos.

Essa lógica ficou evidente quando, em dezembro de 2007, o Ministério Público abriu um processo penal contra nove líderes feministas (todas integrantes da RMCV, duas das quais também ativistas do MAM), sob argumento de que estariam incitando à prática do aborto com a realização de diversos atos de pressão pública para descriminalizar o "aborto terapêutico". Até hoje não existe sentença definitiva desse caso, fazendo com que o processo penal paire como ameaça contra as líderes do movimento, reforçado por um segundo processo administrativo que veio à tona em 2008 . Em setembro do mesmo ano, o Ministério Público emitiu uma ordem de interdição policial ao escritório central do MAM e a duas ONGs aliadas do movimento, aduzindo corrupção administrativa através de projetos de cooperação internacional administrados por 
lideranças do MAM. Esse processo foi encerrado em janeiro de 2009 por falta de provas, mas a interdição policial não só danificou as estruturas físicas da sede do movimento, como ocasionou perda de papelaria e equipamentos, além da suspensão dos projetos de cooperação internacional.

A criminalização da oposição não se limitou às organizações feministas. Em 2008, meses antes da ocupação policial do escritório do MAM, o Conselho Eleitoral cancelou a legenda do $\mathrm{MRS}^{22}$. Com o registro cassado, o MRS não podia mais participar de processos eleitorais com legenda própria, embora pudesse manter suas estruturas partidárias funcionando. Nesse contexto, a aliança com o MAM foi decisiva para a reorganização interna do partido.

O descontentamento de um amplo espectro de organizações e intelectuais com as medidas tomadas por Ortega levou à criação de uma nova estrutura de mobilização: a Unión Ciudadana por la Democracia (UCD). A UCD é uma rede multissetorial que pressiona por reformas eleitorais para erradicar o controle da FSLN sobre as instituições do Estado, e que se transformou na principal estrutura de mobilização contra o governo de Ortega entre 2010 e 2012. Azahalea Solis, da Coordenação Política do MAM, foi indicada como delegada do MAM na UCD e, por suas habilidades como advogada e ativista, acabou assumindo a liderança da rede. Nessa posição, ela convidou Enrique Saenz, presidente do MRS, para integrar a UCD, levando para dentro do novo arranjo a aliança que ambos já mantinham fora dela.

Em 2011, o MRS entra numa coligação com o Partido Liberal Independiente (PLI), situado à direita, e convida a UCD para integrá-la ${ }^{23}$. Como parte do acordo, o partido fica com uma vaga nas postulações para deputado e o nome escolhido é Azahalea Solis, que passa então a assumir os múltiplos papéis de líder do MAM, líder da UCD e candidata a deputada nacional numa coalizão de direita.

Para além de permitir ao MRS atuar nas eleições, a Coordenadoria Política do MAM foi essencial na reestruturação interna que o MRS teve de fazer para se incorporar à aliança com o Partido Liberal. O depoimento do deputado Enrique Sáenz nos ajuda a ilustrar esse ponto:

En las elecciones internas del MRS, donde nosotros elegimos nuestros propios candidatos y representantes ante el PLI, invitamos a una persona de fuera del MRS que hiciera una especie de Presidente de Tribunal Electoral ad hoc que es para hacer el conteo y esas cosas (...). Entonces, ¿quién administró ese proceso? Fue Azahalea. Nosotros como grupo parlamentario nos reunimos todos los lunes y ella es invitada a asistir a las reuniones del

\footnotetext{
$22 \mathrm{O}$ argumento do Conselho Eleitoral para o cancelamento da legenda do MRS foi que o partido não tinha estruturas em mais de $60 \%$ dos municípios, regra contemplada na Lei Eleitoral para considerar a nacionalização das estruturas partidárias.

${ }^{23}$ Sobre a aproximação do MRS com a direita é importante lembrar que a única esquerda na Nicarágua era a FSLN (embora muitos já não o considerem de esquerda) e o MRS. Por isso, para participar da disputa sem legenda própria, o MRS necessariamente deveria compor com a direita.
} 
grupo parlamentario, ya sea por sus habilidades legales, por su capacidad constitucional o porque es simplemente del MAM. Para la cuestión de los estatutos, la Red de Mujeres del MRS incorporaron a las mujeres del MAM para reformar los estatutos del MRS. ¿Eso está en el acuerdo suscrito con el MAM? No, pero el proceso ha venido profundizando formas no escritas (deputado do MRS Enrique Sáenz, entrevista realizada em dezembro de 2012).

Para as feministas do MAM, não fazia sentido "apenas" influenciar o partido no Congresso, sem que ele estivesse preparado para lidar com questões de equidade de gênero. Com essa intenção realizaram cursos de formação em gênero que as feministas do MAM ministrariam aos militantes e deputados eleitos do MRS. As sessões de formação começaram a ser formuladas em 2010 de forma conjunta entre as ativistas do MAM e algumas mulheres dirigentes do MRS.

O trabalho de coordenação avançou e resultou na criação da Red de Mujeres do MRS, uma nova estrutura partidária com direito a ocupar uma cadeira no Diretório Nacional e ter representantes nos diversos diretórios municipais do MRS. A Red de Mujeres do MRS foi oficialmente constituída em 2011 e teve como seus objetivos explícitos "ser reconhecida institucionalmente (no MRS) e entre as organizações de mulheres". Em outras palavras, assumir a função de elo entre o partido e o movimento. O relatório mais recente (2013) que a rede elaborou para o Diretório Nacional considera que um dos maiores resultados da Red de Mujeres do MRS foi ter participado "das atividades das organizações de mulheres", destacando a participação das militantes do partido em marchas feministas pela descriminalização do aborto terapêutico, passeatas contra a impunidade ao feminicídio, episódios de estupros que não foram punidos e diversas atividades comemorativas de datas emblemáticas como 8 de março, 10 de dezembro (Dia Internacional dos Direitos Humanos) e 28 de setembro (data comemorativa da campanha pela legalização do aborto).

Um segundo impacto da Red de Mujeres do MRS tem sido a modificação da correlação de porcentagem de mulheres dentro das estruturas do partido. De acordo com os relatórios internos do MRS, a Red de Mujeres ocupa hoje cadeiras nos diretórios partidários em diversos níveis. Por exemplo, o Diretório Nacional está composto atualmente por $44 \%$ de mulheres e tem uma representante da Red de Mujeres. A mesma correlação existe no Comitê Executivo Nacional e em praticamente todos os 78 diretórios municipais (em que a média de mulheres é de 40\%), sem contar que a presidente do MRS é uma mulher. Essa composição também se repete em outras instâncias mais técnicas, como, por exemplo, o Comitê de Organização, Comitê de Comunicação, Comitê de Formação Política e Tribunal de Estatutos Internos, cujas estruturas são presididas por mulheres. O funcionamento da Red de Mujeres do MRS também ajudou a preparar o partido para as disputas eleitorais seguintes, incrementando a participação das mulheres nas primárias internas. Durante as eleições presidenciais de 2011, por exemplo, a Rede 
estimulou as militantes a realizar campanha interna, a partir de cursos de formação em oratória, imagem, domínio de mídia etc. O objetivo era que durante as eleições internas as mulheres pudessem liderar as listas de pré-candidatos a deputados regionais para o pleito presidencial de novembro de 2011, retomando assim a importância da regra de cota de gênero, que estava praticamente suspensa desde as eleições presidenciais de 2006.

Como é possível perceber, a cassação da legenda do MRS instaurou uma prática instigante para o sistema de partidos no país. Mesmo perdendo uma de suas características distintivas como partido político (disputar eleições com legenda própria), o MRS mantém as estruturas (diretórios, comitês etc.) intactas, a partir das quais conseguiu negociar com a coligação de partidos liderados pelo PLI, em 2011. Como relatado por um deputado do MRS, essas alianças não são legalmente inscritas no Conselho Eleitoral, são portanto alianças informais de um grupo de pessoas na coligação. Nesse contexto, o MAM assume um papel fundamental para o MRS, não só integrando as listas de candidaturas e auxiliando na reformulação interna do partido, mas também ao abrir espaço para a atuação do partido na sociedade. Na Introdução, mencionamos que as feministas políticas justificaram sua aliança com o MRS ao usar a metáfora do partido como um cavalo no qual elas montariam para acessar o sistema político. Após ter a legenda cassada, é o MRS que parece montar no cavalo do movimento para acessar recursos na sociedade civil. Ao fim e ao cabo, é o MRS que começa a agir como movimento, gerando uma espécie de mimetismo entre ambos, como reconhece um dos funcionários do Partido Liberal Independiente ao nos dizer que eles percebem o MRS como sendo "um movimento com estrutura de partido".

Para encerrar esse item, algumas considerações sobre os resultados da aliança MAM-MRS devem ser feitas. De um modo geral, o balanço é ambíguo. Ortega segue dominando o quadro eleitoral: elegeu-se em 1984, 2006, 2011 e é novamente candidato em 2016, embora a oposição continue alegando a manipulação das regras e a falta de transparência que colocaria em xeque os resultados eleitorais ${ }^{24}$. O desempenho do MAMMRS nas eleições de 2006 e 2011 foi abaixo do esperado. Em 2006 elegeu só três deputados, ao obter 5\% do eleitorado nacional, enquanto em 2011 só conseguiu participar das eleições dentro de uma coalizão de direita, liderada pelo PLI, na qual elegeu dois deputados titulares e um suplente. Embora as feministas políticas tenham sido lançadas como candidatas a deputada em 2006 e 2011, nenhuma delas foi eleita ${ }^{25}$.

\footnotetext{
24 Um novo episódio jogou ainda mais dúvidas sobre o processo eleitoral. No momento em que escrevíamos esse texto, o Supremo Tribunal resolveu um litígio interno entre diversas facções do Partido Liberal Independiente, que acabou por impedir que a coligação participasse das eleições presidenciais de 2016. Na resolução, o Tribunal proíbe a coligação de continuar usando a legenda do Partido Liberal Independiente e transfere esse direito para uma das facções que não tem estruturas nem candidatos. Na visão de analistas nicaraguenses, o resultado prático será um processo eleitoral com apenas uma única candidatura, a do presidente Daniel Ortega (FSLN), que postula sua segunda reeleição.

${ }^{25}$ As militantes do MAM candidatas a deputada em 2006 foram Azahalea Solis, Violeta Delgado e Reyna Rodriguez. Em 2011, a candidata foi Azahalea Solis, e em 2016 foi lançada novamente a candidatura de Violeta Delgado.
} 
Diante da dificuldade de obter êxito com o sistema eleitoral vigente, MAM e MRS têm também investido na mobilização social para pressionar por reformas eleitorais e com esse objetivo lideram a rede multissetorial Unión Ciudadana por la Democracia (UCD), que entre 2010 e 2012 se constituiu na principal estrutura de mobilização contra o governo de Ortega, como vimos.

Em termos das políticas públicas, o governo combinou a criminalização do movimento feminista, principalmente o MAM, com a incorporação de algumas de suas pautas. Atualmente a Nicarágua ostenta o título de país com melhor índice de equidade de gênero na América Latina, de acordo com o mais recente relatório do Fórum Econômico Global $^{26}$. Por outro lado, é um país que criminaliza todas as formas de aborto e que tem assistido a um aumento significativo dos indicadores de violência de gênero. Depois de confirmar que não iria reverter a criminalização do aborto terapêutico ${ }^{27}$, o governo começou a promover uma série de medidas orientadas a melhorar a representação política das mulheres no Estado. Assim foram aprovadas a Lei de Paternidade Responsável, a Lei de Igualdade de Oportunidades, reformas à Lei de Municípios para incorporar a quota de $50 \%$ para mulheres em todas as listas de candidaturas para eleição popular (a Lei 50-50) e a lei que criminaliza a violência contra as mulheres e os feminicídios (Lei 779). Os processos de elaboração das políticas foram variados, por exemplo, no caso da lei contra a violência e o feminicídio, a iniciativa foi de uma das organizações do movimento (o Movimiento Maria Elena Cuadra, MEC) e revelou uma intensa interação entre organizações feministas, deputados da bancada de direita e da FSLN e o Supremo Tribunal de Justiça, enquanto a Lei 50-50 surgiu do próprio Executivo e dispensou qualquer processo de consulta às organizações feministas. Seja como for, essas leis tiveram como efeito revigorar a luta do feminismo nacional pela democratização do sistema de partidos e da sociedade nicaraguense como um todo.

No que se refere aos impactos sobre o movimento, por um lado, a aliança MAMMRS permitiu às feministas participarem de espaços políticos institucionalizados que tinham sido vedados pelos embates com a FSLN, mas, por outro lado, essa atuação ampliou a fragmentação e a competição no interior da rede feminista deixando ainda mais distante o sonho das feministas políticas de uma rede única. A atuação intensa nas campanhas eleitorais, inclusive com o lançamento de candidatas do MAM, tem estimulado avaliações na sociedade segundo as quais o MAM estaria muito mais orientado para a disputa pelo poder do Estado do que propriamente para uma reforma democrática do sistema político, o que tem enfraquecido a sua posição no interior da rede do movimento feminista como um todo, principalmente a partir da aproximação com partidos de direita. Outro saldo diz respeito à questão organizacional. Desde 1974, as feministas investem num processo de inovação organizacional com impactos não só

\footnotetext{
${ }^{26}$ Ver: <http://www3.weforum.org/docs/WEF_GenderGap_Report_2013.pdf>. Acesso em: 18 out. 2015.

27 Com isso, a Nicarágua é o terceiro país da América Latina que mais criminaliza o aborto em todas as formas e o sexto no mundo (Larracoechea, 2014, p. 5).
} 
para dentro, mas também para fora do movimento, como vimos. Inovando organizacionalmente as feministas políticas construíram sua identidade, mobilizaram recursos, buscaram alianças e enfrentaram antagonistas visando conquistar um lugar no mundo da política de uma forma não subordinada. O que não é nunca fácil para aqueles que estão à margem. Contudo, no caso das feministas políticas, esse processo se fez a partir de forte mimetismo com a forma organizacional partidária, o que de certa forma está relacionado ao legado organizacional do período revolucionário. A estrutura centralizada e hierárquica, que exacerbou as tensões internas ao movimento com imposições e expulsões de militantes, acabou por colocar em xeque a qualidade de representação dentro do movimento (Chaguaceda, 2011).

\section{A modularidade da autonomia e a zona de interseção ${ }^{28}$}

Nossa contribuição ao debate teórico está diretamente associada aos problemas que tivemos que enfrentar no campo empírico. O primeiro deles nos exigiu recolocar em discussão o debate da autonomia dos movimentos, agora sob uma chave que reconhecesse sua dimensão relacional, histórica e estratégica. Com essa intenção, apresentamos o debate acerca da modularidade da autonomia. O segundo desafio referese ao tema da mudança social. Precisávamos de um framework analítico que nos permitisse falar das mudanças resultantes da aliança entre partido e movimento em uma conjuntura específica e, com esse objetivo, forjamos o modelo da zona de interseção. São essas duas ideias que buscamos elaborar nesse último item.

Ao adotar um marco temporal relativamente amplo, de 1974 a 2016, nossa pesquisa nos permitiu apreender as variações nas relações entre movimentos sociais e partidos ao longo do tempo. Vimos que, em vez da dicotomia autonomia x cooptação, forma como a relação entre os atores fora apreendida no passado, há uma gama mais rica e complexa de interações, aqui identificadas nas três fases: incorporação, ruptura e aliança, essa última dividida em aliança instrumental e aliança por projeto.

Na primeira fase (1974-1989) vimos como a estrutura de mobilização e as pautas do movimento são completamente incorporadas pela FLSN na sua fase pré-partido, e é por meio dessa incorporação que as feministas acessam o sistema político para a realização dos seus interesses. Mas é importante lembrar que se trata de uma acomodação tensa, e essa tensão ficou mais latente de meados para o final da década de 1980 , quando as mulheres começaram a experimentar novos modelos organizacionais, a partir da aproximação com os sindicatos e os coletivos feministas. Essa busca por autonomia organizacional está relacionada com uma consciência feminista nascente, e foi como feministas que elas problematizaram seu lugar na revolução. Esse ponto fica

\footnotetext{
${ }^{28}$ Para o debate sobre a autonomia nas suas múltiplas dimensões do âmbito relacional, assim como a discussão da zona de interseção, ver Meza (2015).
} 
evidente no trecho de entrevista de Ana Criquillon, uma importante liderança do movimento:

la revolución había cuestionado que las mujeres fuéramos solamente para el hogar, la reproducción y la familia. Esa parte ya estaba bien incorporada. Lo que la revolución no abordó fue el tema de la relación hombre-mujer dentro del hogar ni en términos del trato, ni de la división sexual del trabajo o de la participación en la toma de decisiones ni nada de eso. Entonces lo que se comenzó a hacer desde las Secretaría de la Mujer de los sindicatos era evidenciar la contradicción entre lo que pretendían lograr en relación a lo de afuera, con lo que implicaba para dentro. Y eso sí era subversivo (Ana Criquillon, feminista francesa residente na Nicarágua desde 1982, entrevista realizada em janeiro de 2012).

O fim do projeto revolucionário, em 1990, e a consequente perda de poder da FSLN sobre as organizações de esquerda permitiram às feministas avançar com a experimentação iniciada no período anterior, dando início à segunda fase, de 1990 a 2000, que chamamos de fase de ruptura. Essa fase se caracteriza por uma diversificação das redes feministas com a explicitação das diferenças no interior desse campo amplo, tendo como principais pontos de conflito a estrutura organizacional do movimento e a relação com os partidos. Uma tensão que persiste até hoje. A terceira fase, 2001 a 2016, começa com os embates entre as feministas e o governo de Enrique Bolaños, em torno das políticas de gênero. A impermeabilidade do Estado à temática de gênero leva as feministas políticas a investir novamente no esforço de alterar o sistema partidário e com isso influenciar as eleições, no sentido de eleger candidatos favoráveis a uma agenda de gênero. O primeiro passo foi criar o MAM, o segundo, construir uma aliança com o MRS.

Acompanhando esse percurso de 42 anos de relação entre o movimento feminista e os partidos, vimos como a preocupação com a autonomia esteve sempre presente, mesmo no caso das feministas políticas cujo objetivo declarado era atuar no interior do sistema de partidos a partir de uma orientação de gênero. A autonomia era um discurso nativo de natureza valorativa, mas era também uma reivindicação estratégica cujo conteúdo concreto variava em função dos contextos específicos da interação. Por isso dizemos que a autonomia tem natureza modular, no sentido de que seu conteúdo não é predefinido, mas se adapta às circunstâncias da interação.

Autonomia não significa não relação (Tatagiba e Teixeira, 2006); antes, é uma reivindicação discursiva e uma prática de interação que se mostra maleável ao contexto político da interação. As militantes do movimento usaram a autonomia para afirmar distanciamento do sistema de partidos e do Estado, sem declarar uma ruptura completa. O distanciamento Ihes confere o espaço necessário para realizar seus cálculos, definir seus repertórios e planejar futuras alianças, fazendo com que possam costurar relações com as instituições do sistema político, uma vez que definem previamente as pautas para a interação. Ao ser passível de interpretações e conflitos, com um caráter estratégico, a 
autonomia assume uma dimensão processual. Ela é, de fato, a expressão de processos. As feministas vão nomeando os diversos tipos de autonomia gerados, porque elas estão imersas num processo político concreto, seja de separação do partido FSLN (autonomia organizacional e política), seja de diálogo com o Estado (autonomia defensiva) ou bem de negociação com outros atores da cena partidária (autonomia dialogante). Cada categoria se reconhece em um processo concreto e as feministas vão construindo essas diversas categorias no decorrer da ação. Em outras palavras, a autonomia é processual, estratégica e responde a contextos específicos oferecendo as possibilidades para o movimento interagir com as instituições do sistema político, administrando - não sem tensões - os riscos ocasionados por tal interação. Podemos reconhecer essas dimensões a partir do depoimento de Sandra Ramos (Movimiento Maria Elena Cuadra, MEC) quando consultada sobre a visão da autonomia que o feminismo nicaraguense foi elaborando ao longo desses anos todos:

Es que el movimiento de mujeres es como un vaivén de olas. Existen momentos en que el pico de la ola está alto, en otras el movimiento se retrae, pero luego vuelve a subir. Entonces, ese fluir nos da la riqueza de decidir cuando estamos dentro y cuando estamos fuera. $Y$ es en el centro de ese flujo donde yo veo la autonomía. Entonces, la autonomía es ese instrumento que nos permite definir cuando estamos en la ola alta y cuando estamos en retracción. Entonces no podemos partir de un criterio rígido, sino más bien elástico. Ella es la que me permite tener las relaciones, saber hacer las alianzas y saber estar fuera en el momento necesario (Sandra Ramos, líder do MEC, entrevista realizada em maio de 2013).

Tal caráter polivalente - e polissêmico - se fez objeto de disputas no interior do movimento, como vimos. O feminismo, quase de forma unânime, reivindica o caráter (e existência) de um movimento autônomo ao ponto de criar uma organização (que se pretende única) com tal identidade, mas as formas de exercitar essa autonomia produzem tensões. Para uma boa parte das ativistas, a autonomia exige uma separação absoluta do estado e dos partidos políticos (em plural, não só da FSLN em particular), rejeitando ações conjuntas e até mesmo possibilidades de diálogo com tais atores ${ }^{29}$. Para outras, é precisamente a capacidade de diálogo e negociação com esses atores que dá os sinais de amadurecimento e consolidação da autonomia.

Nossa pesquisa também nos permitiu refletir sobre como a relação movimentopartido se vincula a um dos temas centrais da agenda de pesquisa dos movimentos

\footnotetext{
${ }^{29}$ Durante um dos nossos encontros com Maria Teresa Blandón, ela nos disse literalmente: "El MAM dice que nosotras tenemos una autonomía pro-activa y dialogante. Creo que el movimiento feminista está colocado en otro lugar. En esto de lo que algunas feministas del MAM llamarían autonomía defensiva. Queremos ser autónomas y ni siquiera, escúchame bien, ni siquiera empezar un diálogo con los partidos políticos. Estamos en un estado de negación de su papel. Sabemos que existen, que están ahí, que ganan elecciones, que deciden sobre las leyes etc., pero pensamos que la posibilidad de que dialoguen con los movimientos sociales y particularmente con las feministas es difícil, son condiciones que no están dadas, no vemos posibilidades de diálogo" (Maria Teresa Blandón, entrevista realizada em maio de 2013).
} 
sociais, que é a mudança social. No nosso caso específico, movimentos sociais e partidos se aliaram com o objetivo de democratizar o sistema de partidos e o Estado, a partir de uma agenda de gênero. Mais do que avaliar o quanto ambos foram ou não bemsucedidos nessa tarefa - o que excederia os objetivos do artigo -, buscamos a construção de um framework analítico que nos permitisse identificar os processos de mudança que o encontro entre partidos e movimento gerou em ambos e no contexto da interação. Com esse objetivo, formulamos o framework analítico da zona de interseção.

Podemos definir a zona de interseção como um espaço transacional moldado pelos vínculos que movimentos sociais e partidos ativam para responder às oportunidades e ameaças do contexto político. Ou seja, a zona de interseção só existe quando os atores decidem investir numa ação pactuada ao longo do tempo. Alguns mecanismos são importantes para que essa zona seja criada, como, por exemplo, o ativismo de fronteira, a ação dos brokers, o compartilhamento de projetos políticos, a múltipla militância, como a literatura tem nos sugerido. Contudo, esses conceitos explicam como se constroem vínculos entre os atores que geram oportunidades para a coordenação da ação entre campos. Mas eles não nos permitem compreender o que acontece quando esses atores decidem coordenar suas ações com vistas a promover mudanças no ambiente no qual atuam. O conceito da zona de interseção busca tratar diretamente disso. A Figura 1 mostra uma representação gráfica do conceito:

Figura 1

A zona de interseção

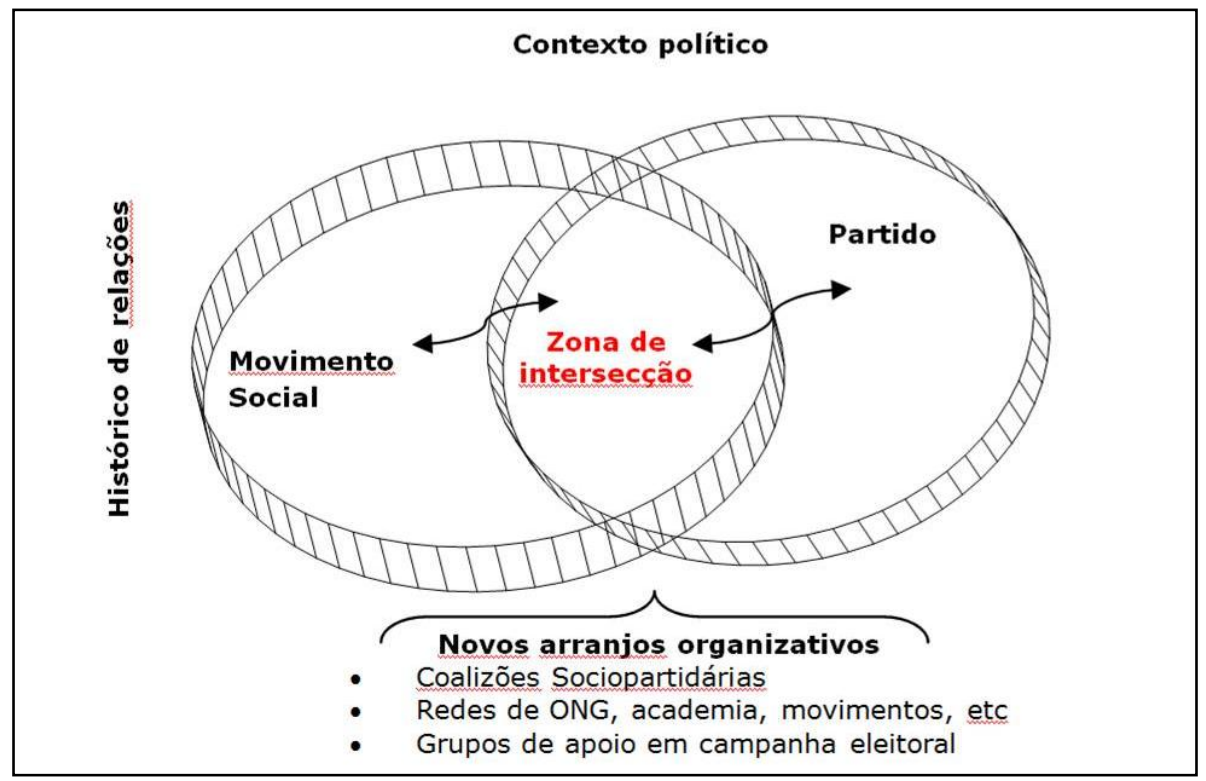

Fonte: Meza (2015, p. 198). 
Em outras palavras, a zona de interseção é suficientemente moldável para estimular novas relações, incorporando outros parceiros (novos partidos, outros movimentos etc.) e alterando os arranjos organizativos do entorno, ao mesmo tempo em que impacta as estruturas internas do movimento e do partido. Esses impactos de mão dupla também rebatem sobre a própria interseção, uma vez que as transformações registradas nas estruturas de partido e movimento social estimulam variadas dinâmicas que atualizam a transação (ou até mesmo acabam com ela). Os fenômenos criados nessa zona também estimulam arranjos organizativos no entorno em que ela acontece. As transações dos atores que atravessam essa região intermédia visam provocar mudanças no contexto político e, para isso, geram novas redes, incitam novas alianças, interferem em diversos tipos de coordenação com outros atores para obter mudanças políticas e impactar o Estado.

Por fim, a zona de interseção não age como fronteira entre os atores, mas sim como espaço de transação. À diferença da fronteira, a zona de interseção não separa nem distingue os atores, mas os reúne em torno de interesses, agendas e objetivos com potencialidades de gerar transformações políticas. Assim, essa zona é capaz não só de vincular espaços estruturais, mas também de colocar em diálogo contextos, estórias vividas e estratégias por mudanças políticas.

A zona de interseção é o espaço intermédio, construído na relação entre o movimento e o partido, que permitiu diminuir a distância entre eles, sem eliminar as fronteiras que sustentam, em última instância, a reivindicação da autonomia recíproca. Por isso, não podemos falar em zona de interseção na fase da incorporação (1974-1989), porque nesse momento, embora o movimento de mulheres e a FSLN se relacionem e sobre essa base desenvolvam estratégias de luta comuns orientadas por um mesmo projeto de sociedade, não está assegurado a ambos o reconhecimento de sua autonomia programática e organizacional. Na fase seguinte, a da ruptura, o movimento de mulheres constrói sua agenda e suas organizações próprias. Mas os conflitos com a FSLN atingem tal nível que os vínculos que permitiriam o trânsito entre as fronteiras do partido e do movimento são cortados, e não se cria um espaço intermédio para a construção da ação comum. Já na terceira fase, a relação MAM-MRS cria essa zona de interseção, na qual os atores reconhecem sua autonomia recíproca e sobre essa base enfrentam os desafios de coordenar suas ações e provocar mudanças.

Esperamos com este artigo contribuir com o avanço da agenda de pesquisa sobre a relação entre movimentos sociais e partidos, a partir da realidade latino-americana recente. Obviamente trata-se de uma agenda de pesquisa que apenas se iniciou. Hoje, dois caminhos se apresentam como particularmente importantes para o avanço da análise. Em primeiro lugar, precisamos enfrentar o como da interação no interior da zona de interseção. Nossa análise se concentrou na compreensão dos motivos que explicam a decisão dos atores de investirem na aliança e nos resultados mútuos dessa aliança sobre os atores e o contexto da interação. Mas não conseguimos chegar ao como os atores 
interagem no espaço intermédio, como negociam suas identidades e como resolvem concretamente os dilemas implicados na coordenação de suas ações. Uma forma interessante de avançar nesse ponto é por meio da etnografia política. O segundo caminho é investir na análise comparada. O que fizemos aqui foi um estudo de caso, a partir de um país centro-americano com uma realidade política particular, marcada pelos conflitos e conquistas do período revolucionário, o que não nos autoriza generalizações. O desafio agora é avaliar até que ponto o modelo construído ajuda a explicar a relação movimento-partido em outros contextos e envolvendo outros movimentos.

Humberto Meza - Doutor em Ciência Política pelo Instituto de Filosofia e Ciências Humanas da Unicamp, e membro do Núcleo de Pesquisa em Participação, Movimentos Sociais e Ação Coletiva (Nepac-Unicamp). Pesquisador do Observatório das Metrópoles-UFRJ. E-mail: <meza.humberto@gmail.com>.

Luciana Tatagiba - Professora livre-docente do Departamento de Ciência Política, do Instituto de Filosofia e Ciências Humanas, da Unicamp, e coordenadora do Núcleo de Pesquisa em Participação, Movimentos Sociais e Ação Coletiva (Nepac-Unicamp).

E-mail: <tatagiba@g.unicamp.br>.

\section{Referências bibliográficas}

Abers, R.; OliveirA, M. S. "Nomeações políticas no Ministério do Meio Ambiente (2003-2013): interconexões entre ONGs, partidos e governos". Opinião Pública, Campinas, vol. 21, n², p. 336364, ago. 2015.

Abers, R.; Serafim, L.; TATAgibA, L. "Repertórios de interação Estado-sociedade em um Estado heterogêneo: a experiência na era Lula". Dados, Rio de Janeiro, vol. 57, n² 2, p. 325-357, 2014.

ABERS, R.; Von BüLow, M. "Movimentos sociais na teoria e na prática: como estudar o ativismo através da fronteira entre Estado e sociedade?". Sociologias, Porto Alegre, ano 3, n 28, p. 52-84, set.-dez. 2011.

Alvarez, S.; EscobAr, A. Theoretical and political horizons of change in contemporary Latin American social movements. In: Escobar, A.; Alvarez, S. (eds.). The making of social movements in Latin America: identity, strategy and democracy. Boulder: Westview Press, 1992.

Alvarez, S.; Dagnino, E.; Escobar, A. Cultura e política nos movimentos sociais latino-americanos: novas leituras. Belo Horizonte: Editora da UFMG, 2000.

AMENTA, E.; HALFMANN, S. Opportunity knocks: the trouble with political opportunity and what you can do about it. In: GoodWIN, J.; JASPER, J. (eds.). Contention in context: political opportunities and the emergence of protest. Stanford: Stanford University Press, 2012.

Arnson, C. J.; Perales, J. R. The 'New Left' and democratic governance in Latin America. Washington D.C.: Woodrow Wilson Center, 2007.

BAB, F. Después de la revolución. Género y cultura política en la Nicaragua neoliberal. INHCA-UCA, Managua, 2012. 
BALDizón, J. A. El Frente Sandinista de Liberación Nacional y sus órganos partidistas locales: una primera aproximación a los municipios de Boaco y Estelí. Guatemala: Flacso, 2004.

BLIKSTAD, K. D. "O agir coletivo nas interfaces da sociedade civil e do sistema político. O caso da atuação do movimento de moradia de são Paulo sobre a política pública de habitação". Dissertação de Mestrado em Ciência Política. Unicamp, Instituto de Filosofia e Ciências Humanas, Campinas, 2012.

BosChI, R. R.; VAlLAdARES, L. P. "Problemas teóricos na análise de movimentos sociais: comunidade, ação coletiva e o papel do Estado". Espaço e Debate, Rio de Janeiro, no 8, jan.-abr., 1983.

CANnon, B.; PeAdaR, K. Civil society and the State in left-led Latin America. London: Zed Books, 2012.

CARDoso, R. "Movimentos sociais na América Latina". Revista Brasileira de Ciências Sociais, São Paulo, n 3, vol. 1, fev. 1987.

. A trajetória dos movimentos sociais. In: DAGNino, E. (ed.). Os anos 90: política e sociedade no Brasil. São Paulo: Brasiliense, 1994.

CASTRO, F.; KoOnings, K.; Wiesebron, M. Brazil under the Workers' Party: continuity and change from Lula to Dilma. London: Palgrave, 2014.

ChAGUaCeda, A. "El movimiento de mujeres y las luchas sociales por la democratización en la Nicaragua postrevolucionaria (1990-2010)". Revista Encuentro, Managua, n 89, p. 39-62, 2011.

Coraggio, J. L.; LAVILLE, J. Reinventar la izquierda en el siglo XXI: hacia un diálogo norte-sur. Los Polvorines. Buenos Aires: Clacso, 2014.

CUADRA, E. E.; JimenEZ, J. El movimiento de mujeres y la lucha por sus derechos: movimientos sociales y ciudadanía en Centroamérica. Managua: Cinco, 2010.

D'Araújo, M. C. (ed.). Governo Lula: contornos sociais e políticos da elite no poder. Rio de Janeiro: CPDOC, 2007.

DAGNino, E. Sociedade civil, espaços públicos e a construção democrática no Brasil. In: DAGnino, E. (ed.). Sociedade civil e espaços públicos no Brasil. São Paulo: Paz e Terra, 2002.

Dagnino, E.; Olvera, A.; PAnfichi, A. (eds.). A disputa pela construção democrática na América Latina. São Paulo: Paz e Terra, 2006.

DAGNINO, E.; TATAGIBA, L. "Mouvements sociaux et participation institutionnelle: répertoires d'action collective et dynamiques culturelles dans la difficile construction de la démocratie brésilienne". Revue Internationale de Politique Comparé, vol. 17, 2010.

DAgnino, E.; TeIXEIRA, A. C. C. "The participation of civil society in Lula's government". Journal of Politics in Latin America, Hamburg, vol. 6, n 3, p. 39-66, 2014.

D'AVILA FilHo, P.; SzWAKo, J.; RomÃo, W. "Dossiê representação, participação e intermediação". Interseções: Revista de Estudos Interdisciplinares, Rio de Janeiro, vol. 17, n 1, 2015.

DAVIS, D. "The power of distance: re-theorizing social movements in Latin America". Theory and Society, vol. 28, n 4, p. 585-638, August 1999.

DOWBOR, M. "Arte da institucionalização: estratégias de mobilização dos sanitaristas (19742006)". Tese de Doutorado em Ciência Política. Faculdade de Filosofia, Letras e Ciências Humanas, FFLCH/USP, São Paulo, 2012. 
EL NUEVO DIARIO. "Votos vergonzantes". Nacional (online). Disponível em: <http://archivo.elnuevodiario.com.ni/nacional/193748-votos-vergonzantes/>. Acesso em: 10 fev. 2016.

Ferro, M. C. T. "Participación social en la construcción de la Política Nacional para la Población en Situación de Calle en Brasil: alcances y límites". In: Anais do XXIX Congreso de la Asociación de Estudios Latinoamericanos Lasa, Toronto, Canadá, 6-9 Octubre 2010.

. ."Desafíos de la participación social: alcances y límites de la construcción de la política nacional para la población en situación de calle en Brasil". Dissertação de Mestrado, Programa de Ciencia Política y Sociologia, Flacso, Argentina, 2011.

Giugni, M.; MCAdam, D.; Tilly, C. (eds.). From contention to democracy. Lanham: Rowman \& Littlefield Publishers, 1998.

Goldstone, J. A. Bridging institutionalized and noninstitutionalized politics. In: GoldSTONE, J. (ed.). States, parties and social movements. Cambridge: Cambridge University, 2003.

GOODWIN, J.; JASPER, J. "Caught in a winding, snarling vine: the structural bias of political process theory". Sociological Forum, vol. 14, n 1, p. 27-54, 1999.

Gurza lavalle, A.; Romão, W.; Zaremberg, G. "Partidos políticos e innovación democrática: más allá de purezas y perversiones". Revista Mexicana de Ciencias Políticas y Sociales, ano LIX, n²20, p. 21-54, Enero-Abril 2014.

Gurza LaVAlle, A.; SzWAKo, J. "Sociedade civil, Estado, autonomia: argumentos, contra-argumentos e avanços no debate". Opinião Pública, Campinas, vol. 21, nº 1, p. 157-187, abr. 2015.

GutierRes, K. A. "Projetos políticos, trajetórias e estratégias: a política de assistência social entre o partido e o Estado". Tese de Doutorado em Ciências Sociais, Unicamp, Instituto de Filosofia e Ciências Humanas, Campinas, 2015.

HeLLMAN, J. A. The study of new social movements in Latin America and the question of autonomy. In: Escobar, A.; Alvarez, S. (eds). The making of social movements in Latin America: identity, strategy and democracy. Boulder: Westview Press, 1992.

JACOBI, P. Movimentos sociais políticas públicas: demandas por saneamento básico e saúde. São Paulo: Cortez, 1989.

KAMPWIRTH, K. Revolución, feminismo y antifeminismo en Nicaragua. In: Lebon, N.; MAIER, E. (eds.). De lo privado a lo público: 30 años de lucha ciudadana de las mujeres en América Latina. Eds. N. Lebon e E. Maier. México: Siglo XXI, 2006.

KowARICK, L. "Movimentos urbanos no Brasil contemporâneo: uma análise da literatura". Revista Brasileira de Ciências Sociais, nº 3, vol. I, 1987.

Kriese, H. Political context and opportunities. In: Snow, D. A.; Soule, S. A.; Kriesi, H. (eds.). The blackwell companion to social movements. Oxford: Blackwell Publishing Ltd, p. 67-90, 2004.

LACOMBE, D. "¿'Luchar contra el peor escenario'? construcción del movimiento autónomo de mujeres y debates de la militancia feminista en el contexto pre-electoral Nicaragüense (2004-2006)". In: Anais do XXIX Congreso de la Asociación de Estudios Latinoamericanos Lasa, Toronto, Canadá, 6-9 Octubre 2010.

LARRACOeCheA, E. "¿Ciudadanía Cero? El 'Hambre Cero' y el empoderamiento de las mujeres en Nicaragua". Paper Grupo Venancia. Febr. 2014 
LEITÃo, L. R. "Oportunidades políticas e repertórios de ação: o movimento negro e a luta de combate à discriminação racial". Tese de Doutorado em Sociologia, Universidade Federal do Rio Grande do Sul, Instituto de Filosofia e Ciências Humanas, Porto Alegre, 2012.

LOSEKANN, C. "A presença das organizações ambientalistas da sociedade civil no governo Lula (20032007) e as tensões com os setores econômicos". Tese de doutorado em Ciência Política.

Universidade Federal do Rio Grande do Sul, Porto Alegre, 2009.

LUCIAK, I. After the revolution: gender and democracy in El Salvador, Nicaragua and Guatemala. Baltimore: Johns Hopkins University Press, 2001.

MAM. Acuerdo político entre el Movimiento Autónomo de Mujeres de Nicaragua (MAM) y la Alianza Movimiento de Renovación Sandinista (MRS). Managua, 15 junio 2006.

MAREgA, M. A Nicarágua sandinista. São Paulo: Brasiliense, 1982.

Documento Político. Política y ciudadanía de las mujeres. Bases de la refundación del Movimiento Autónomo de Mujeres de Nicaragua. Matagalpa/Managua, Febrero 2006.

MCADAM, D.; TARROW, S. "Movimentos sociais e eleições: por uma compreensão mais ampla do contexto político da contestação". Sociologias, vol. 13, n² 28, p. 18-51, 2011.

McAdam, D.; TARRow, S.; Tilly, C. Dynamics of contention. Cambridge: Cambridge University Press, 2001.

MeYer, D.; Jenness, V.; Ingram, H. (eds.). Routing the opposition: social movements, public policy, and democracy. Minneapolis: University of Minnesota Press, 2005.

MEYER, D.; TARROW, S. The social movement society. Oxford: Rowman \& Littlefield, 1998.

MeZA, H. M. "Autonomia em movimento. Análise da trajetória das relações do movimento de mulheres com os partidos políticos na Nicarágua pós-revolucionária". Tese de Doutorado em Ciência Política, IFCH, Universidade Estadual de Campinas, 2015.

Miguel, L. F.; Biroli, F. Feminismo e política: uma introdução. São Paulo: Boitempo, 2014.

MolyNeUX, M. Mobilisation without emancipation? Women's interests, State and revolution in Nicaragua. In: MolYNEUX, M. (ed.). Women's movements in international perspective. Latin America and Beyond. London: Institute of Latin American Studies, 2001.

MURGUiALDAY, C. Nicaragua, revolución y feminismo (1977-1989). Madrid: Revolución, 1990.

ORTEGA HegG, M. Las relaciones gobierno: sociedad civil, a inicios de la administración del presidente Daniel Ortega. Managua: Ed. UCA, 2008.

PENNA, C. Conexões e controvérsias no Incra de Marabá: o Estado como um ator heterogêneo. Rio de Janeiro: Garamond, 2015.

POLLETTA, F. "Snarls, quacks and quarrels: culture and structure in political process theory". Sociological Forum, vol. 14, n 1, p. 63-70, mar. 1999.

PRADO, S. Modelos de participación ciudadana y presupuestos municipales. Entre los CDM y los CPC. Managua: Ceap, 2007.

PUIG, M. S. "El regreso de Ortega: los primeros pasos de su segunda administración". Revista de Ciencia Política, Santiago, vol. 28, n 1, p. 287-303, 2008.

PUIG, M. S.; CLOSE, D. (eds.). The sandinistas and Nicaragua since 1979. Boulder: Lynne Rienner Publishers, 2012. 
SANTIUSTE, C. S. "Del monopolio del poder a la competencia electoral: la incompleta transformación del FSLN en los 90". América Latina Hoy, n²7, p. 89-122, 2001.

Santos, C. N. Movimentos urbanos no Rio de Janeiro. Rio de Janeiro: Zahar, 1981.

SERAFIM, L. "Participação no governo Lula: as pautas da reforma urbana no Ministério das Cidades (2003-2010)". Tese de Doutorado em Ciências Sociais, Instituto de Filosofia e Ciências Humanas, Unicamp, Campinas, 2013.

Silva, M.; OliveirA, G. L. "A face oculta(da) dos movimentos sociais: trânsito institucional e interseção Estado-movimento: uma análise do movimento de economia solidária no Rio Grande do Sul". Sociologias, vol. 13, n²8, p. 86-125, 2011.

TATAGIBA, L. Relação entre movimentos sociais e instituições políticas no cenário brasileiro recente. Reflexões em torno de uma agenda preliminar de pesquisa. Mímeo, 2009.

TATAGIBA, L.; BLIKSTAD, K. "Como se fosse uma eleição para vereador: dinâmicas participativas e disputas partidárias na cidade de São Paulo. Lua Nova, São Paulo, vol. 84, p. 175-217, 2011.

TatagibA, L.; Teixeira, A. C. "Participação e democracia: velhos e novos desafios". Civitas, Porto Alegre, vol. 6, nº 1, p. 223-240, 2006.

. "Efeitos combinados dos movimentos de moradia sobre os programas habitacionais autogestionários". Revista de Sociologia e Política (online), vol. 24, nº 58, p. 85-102, 2016.

TeIXEIRA, A. C. "Para além do voto: uma narrativa sobre a democracia participativa no Brasil (19752010)". Tese de Doutorado em Ciências Sociais, IFCH, Universidade Estadual de Campinas, 2013.

Tilly, C. Popular contention in Great Britain, 1758-1834. Cambridge, Ma: Harvard University Press, 1995.

. Contentions performances. Cambridge: Cambridge University Press, 2008.

WeYLAND, K.; MADRID, R.; HUNTER, W. Left governments in Latin America: successes and shortcomings. New York: Cambridge University Press, 2010.

ZibeCHI, R. "Movimientos sociales: nuevos escenarios y desafíos inéditos". Osal, Buenos Aires, ano VII, n²1, p. 221-230, Clacso, September-December 2011.

Zimmermann, M. A revolução nicaraguense. São Paulo: Unesp, 2006.

\section{Resumo}

Movimentos sociais e partidos políticos: as relações entre o movimento feminista e o sistema de partidos na Nicarágua (1974-2012)

Este artigo busca contribuir com o debate teórico sobre as relações entre movimentos sociais e partidos políticos, a partir de um estudo de caso sobre as relações entre o movimento feminista e o sistema de partidos na Nicarágua, ao longo da construção democrática nicaraguense, entre 1974 e 2012. A pesquisa de campo foi realizada entre 2011 e 2014 e consistiu da realização de entrevistas com lideranças do movimento feminista e dos partidos políticos, análise documental e observação participante nos eventos do movimento. A partir dos desafios colocados pela empiria, 0 artigo avança em dois debates principais: a natureza modular da autonomia e a zona de interseção. No 
primeiro, buscamos destacar a natureza relacional, histórica e estratégica da reivindicação da autonomia; no segundo, nosso tema são os impactos mútuos dessas relações sobre os atores e o contexto político da interação.

Palavras-chaves: movimentos sociais; partidos políticos; feminismo; Nicarágua

\begin{abstract}
Social movements and political parties: relationships between the feminist movement and the political party system in Nicaragua (1974-2012)

This article aims to contribute to the theoretical debate over the relationship between social movements and political parties. The analysis presented relies on a case study of the relationship between the feminist movement and the party system in Nicaragua, during the country's democratic development between 1974 and 2012. The field research was done from 2011 to 2014 and consisted of interviews with leaders of the feminist movement and the various political parties, analysis of key documents, and participant observation in several of the movement's events. In order to respond to certain empirical challenges, this article advances two key debates on the modular nature of autonomy and the intersection zone. In the first debate, we highlight the historical, strategic, and relational nature of autonomy. In the second, we focus on the mutual impacts of this relationship on the actors and political context
\end{abstract}

Keywords: social movements; party politics; feminism; Nicaragua

\title{
Resumen
}

Movimientos sociales y partidos políticos: las relaciones entre el movimiento feminista y el sistema de partidos en Nicaragua (1974-2012)

Este artículo busca contribuir con el debate teórico sobre las relaciones entre movimientos sociales y partidos políticos, a partir del estudio de caso sobre las relaciones entre el movimiento feminista y el sistema de partidos políticos en Nicaragua, a lo largo de la construcción democrática nicaragüense entre 1974-2012. La investigación de campo se realizó entre 2011 y 2014 y consistió en la realización de entrevistas con líderes del movimiento feminista y de los partidos políticos, análisis documental y observación participante en los eventos del movimiento. Partiendo de los desafíos del campo empírico, este ensayo avanza sobre dos debates centrales: la naturaleza modular de la autonomía y la zona de intersección. En el primero, pretendemos destacar la naturaleza relacional, histórica y estratégica de reivindicación de la autonomía. En el segundo, nuestro tema son los impactos mutuos de esa relación sobre los actores y el contexto político de la interacción.

Palabras claves: movimientos sociales; partidos políticos; feminismo; Nicaragua

\section{Résumé}

Mouvements sociaux et partis politiques: les relations entre le mouvement féministe et le système des partis au Nicaragua (1974-2012)

Cet article vise à contribuer au débat théorique sur la relation entre les mouvements sociaux et les partis politiques à partir d'une étude de cas sur la relation entre le mouvement féministe et le système des partis au Nicaragua au cours de la construction démocratique du Nicaragua entre 1974 et 2012. L'étude sur le terrain a été réalisée entre 2011 et 2014 et comprenait des entrevues avec les dirigeants du mouvement féministe et des partis politiques, l'analyse de documents et l'observation participante aux événements du mouvement. L'article aborde deux grands débats: la nature modulaire de l'autonomie et la zone d'intersection. Dans le premier, nous cherchons à mettre en évidence la nature relationnelle, historique et stratégique de la revendication de l'autonomie; 
dans le second, nous examinons l'impact mutuel de ces relations sur les acteurs et sur le contexte politique de l'interaction.

Mots-clés: mouvements sociaux; partis politiques; féminisme; Nicaragua

Artigo submetido à publicação em maio de 2015.

Versão final aprovada em julho de 2016. 